\title{
Experimental Study of Cement - Sandstone/Shale - Brine - $\mathrm{CO}_{2}$ Interactions
}

\author{
Susan A Carroll, Walt W McNab and Sharon C Torres
}

\begin{abstract}
Background: Reactive-transport simulation is a tool that is being used to estimate long-term trapping of $\mathrm{CO}_{2}$, and wellbore and cap rock integrity for geologic $\mathrm{CO}_{2}$ storage. We reacted end member components of a heterolithic sandstone and shale unit that forms the upper section of the In Salah Gas Project carbon storage reservoir in Krechba, Algeria with supercritical $\mathrm{CO}_{2}$, brine, and with/without cement at reservoir conditions to develop experimentally constrained geochemical models for use in reactive transport simulations.

Results: We observe marked changes in solution composition when $\mathrm{CO}_{2}$ reacted with cement, sandstone, and shale components at reservoir conditions. The geochemical model for the reaction of sandstone and shale with $\mathrm{CO}_{2}$ and brine is a simple one in which albite, chlorite, illite and carbonate minerals partially dissolve and boehmite, smectite, and amorphous silica precipitate. The geochemical model for the wellbore environment is also fairly simple, in which alkaline cements and rock react with $\mathrm{CO}_{2}$-rich brines to form an Fe containing calcite, amorphous silica, smectite and boehmite or amorphous $\mathrm{Al}(\mathrm{OH})_{3}$.

Conclusions: Our research shows that relatively simple geochemical models can describe the dominant reactions that are likely to occur when $\mathrm{CO}_{2}$ is stored in deep saline aquifers sealed with overlying shale cap rocks, as well as the dominant reactions for cement carbonation at the wellbore interface.
\end{abstract}

\section{Background}

Carbon dioxide is actively being stored at depth in a sandstone saline reservoir as part of the In Salah Gas Project in Krechba, Algeria [1]. It is one of few commercial scale $\mathrm{CO}_{2}$ storage projects and serves as an important platform to study the scientific and technical issues for safe and effective long-term $\mathrm{CO}_{2}$ storage in deep saline reservoirs [2-11].

Wellbores are a potential risk pathway for leakage of $\mathrm{CO}_{2}$ from the storage reservoir to overlying drinking water aquifers and back into the atmosphere. Carbonation of cements, used in wellbores to seal off fluid flow from the reservoir, can bring about changes in permeability and alter the movement of fluids within the wellbore environment. Field, experimental and modeling studies suggest that carbonation of hydrated cements lowers porosity and has the potential to heal fractures within the cement [12-18].

\footnotetext{
* Correspondence: carroll6@llnl.gov

* Correspondence: carroll6@llnl.gov
Lawrence Livermore National Laboratory, 7000 East Avenue, Livermore CA 94550, USA
} 44550, USA

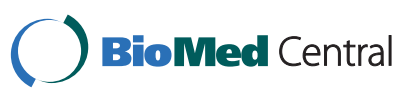

(C) 2011 Carroll et al; licensee Chemistry Central Ltd. This is an Open Access article distributed under the terms of the Creative Commons Attribution License (http://creativecommons.org/licenses/by/2.0), which permits unrestricted use, distribution, and reproduction in any medium, provided the original work is properly cited.
Risk of leakage from a $\mathrm{CO}_{2}$ storage reservoir would be significantly reduced if the $\mathrm{CO}_{2}$ could be stored as a solid carbonate mineral and if these reactions improved the seal within the cap rock above the reservoir. Field and laboratory experiments have shown mineral dissolution in $\mathrm{CO}_{2}$-rich brines leads to increased concentrations of $\mathrm{Ca}, \mathrm{Fe}$, and $\mathrm{Mg}$ and, in some cases, to the formation of carbonate minerals [19-24]. The amount of $\mathrm{CO}_{2}$ stored as carbonate minerals over geologic times estimated from reactive transport simulations varies substantially and depends on the reaction rates and the amount of $\mathrm{CO}_{2}$ injected into the subsurface [25-30]. The possibility of even small amounts of carbonate mineralization in shale cap rock may significantly improve seal integrity by reducing porosity. Simulation results suggest seal integrity is enhanced due to carbonate mineral precipitation after 100 years of reaction with $\mathrm{CO}_{2}$-rich fluids [31]. Another modeling study predicts that redistribution of calcite within $0.1 \mathrm{~m}$ of the cap rock - reservoir interface effectively seals reservoir from the overlying strata [32].

The focus of this work was to determine the key geochemical reactions involving common cements used in 
wellbore construction, formation mineralogy, and supercritical $\mathrm{CO}_{2}$ stored at the Krechba site. We reacted the end member components of the heterolithic sandstone and shale unit that forms the upper section of the carbon storage reservoir with supercritical $\mathrm{CO}_{2}$ and representative brine with and without cement at $95^{\circ} \mathrm{C}$ and $10 \mathrm{MPa}$ in gold bag autoclaves. Separate cement experiments without $\mathrm{CO}_{2}$ were conducted to measure cement hydration at temperature prior to the injection of $\mathrm{CO}_{2}$. The experimental results can be used to develop geochemical models for estimating long-term trapping of $\mathrm{CO}_{2}$, and wellbore and cap rock integrity at the Krechba site.

\section{Methods}

\section{Materials}

The heterolithic sandstone and shale in units C10.2 and C10.3 form the upper section of the carbon storage reservoir at the Krechba Field, In Salah, Algeria. Reported mineralogy among 17 core samples collected from Krechba reservoir ranged from a quartz-dominated sandstone to a shale-like material containing abundant illite clay [33]. Iron-rich chlorite appears as coatings on quartz grains in the sandstone and in abundances as high as 30 percent by volume in the shale. Other aluminosilicates include minor quantities (e.g., typically less than 5 percent) of kaolinite and feldspar. Carbonate phases have been described as siderite [33], ankerite plus dolomite (unpublished mineralogical analyses conducted by Statoil), or calcite (unpublished XRD analyses of Krechba core samples). The shale end member, Sample 14, consisted of 44\% illite, $30 \%$ chlorite, $20 \%$ quartz, $4 \%$ kaolinite, $2 \%$ feldspar and trace amounts of pyrite by weight. The sandstone end member, Sample 7, consisted of $88 \%$ quartz, $6 \%$ chlorite, $4 \%$ kaolinite and $2 \%$ siderite by weight. Limited availability of the heterolithic sandstone and shale necessitated the use of rock fragments in the experiments rather than a well-defined powdered size fraction.
The powdered class $G$ oil well cement used in the experiments was provided by Mountain Cement Company and consists of $56 \% \mathrm{Ca}_{3} \mathrm{SiO}_{5}, 39 \% \mathrm{Ca}_{2} \mathrm{SiO}_{4}, 5 \% \mathrm{Ca}_{3} \mathrm{AlO}_{4.5}$, $+0.5 \% \mathrm{Na}_{2} \mathrm{O}$ and $\mathrm{K}_{2} \mathrm{O}$ by weight as determined by standard ASTM C 150. In some experiments small amounts of bentonite were added to the cement to reflect mixtures identified in well logs from the Krechba site (bentonite to cement ratio $=1: 39$ by weight). Any curing of the cement occurred in the reaction vessels at the experimental conditions. Combination of powdered cement and rock fragments did not compromise the results because the primary objective of the experiments was to determine the dominant geochemical reactions controlling the solution composition.

Initial solutions were distilled and deionized water, $0.13 \mathrm{~m} \mathrm{CaCl}_{2}$, and synthetic Krecha brine consisting of 1.8 molal $\mathrm{NaCl}, 0.55$ molal $\mathrm{CalCl}_{2}$, and 0.1 molal $\mathrm{MgCl}_{2}$. All salts used to synthesize the brines were reagent grade. The experiments were conducted in a synthetic brine to capture the major ion chemistry measured at the site. A more complex reservoir brine was not used to avoid masking relevant geochemical reactions. High purity liquid $\mathrm{CO}_{2}$ was pressurized at temperature and pressure to generate supercritical $\mathrm{CO}_{2}$ for the experiments.

\section{Cement Hydration Experiments}

Distilled and deionized, $0.13 \mathrm{~m} \mathrm{CaCl}_{2}$, and synthetic Krechba solutions were used to determine ion activity products for cement hydration at different solid:solution ratios at 115 and $95^{\circ} \mathrm{C}$ (Table 1). Solutions and solids were reacted in teflon-lined Parr reaction vessels, sealed, and placed into an oven to maintain temperature. Sealed reaction vessels were quenched in cold water prior to taking filtered aqueous samples for chemical analyses. Solids were washed with distilled and deionized water and dried at $60^{\circ} \mathrm{C}$ prior to analysis by an environmental scanning

Table 1 Cement Hydration Experiments

\begin{tabular}{|c|c|c|c|c|c|c|}
\hline ID & Solid & Solution & Solid:Soln $(g / g)$ & $\mathrm{T}^{\circ} \mathrm{C}$ & Days & $\mathrm{pH}(\mathrm{c}, 25)$ \\
\hline G3 & A & $0.13 \mathrm{~m} \mathrm{CaCl}_{2}$ & $1: 10$ & 115 & 43 & 11.9 \\
\hline G6 & A & Brine & $1: 10$ & 115 & 43 & not measured \\
\hline G7 & B & MQ water & $1: 10$ & 115 & 58 & 12.2 \\
\hline G8 & B & MQ water & $1: 10$ & 115 & 87 & 12.3 \\
\hline G9 & B & MQ water & $2: 10$ & 115 & 58 & 12.3 \\
\hline G10 & B & MQ water & $2: 10$ & 115 & 87 & 12.1 \\
\hline G11 & B & MQ water & $1: 10$ & 95 & 74 & 12.3 \\
\hline G12 & B & MQ water & $2: 10$ & 95 & 43 & 12.3 \\
\hline G13 & B & MQ water & $2: 10$ & 95 & 74 & 12.1 \\
\hline G14 & B & Brine & $1: 10$ & 95 & 88 & 11.4 \\
\hline G15 & B & Brine & 2:10 & 95 & 88 & 12.3 \\
\hline
\end{tabular}

A indicates Class G cement, B indicates Class G cement plus bentonite ( $39 \mathrm{~g}$ cement to $1 \mathrm{~g}$ bentonite), and Brine indicates 1.8 molal NaCl, 0.55 molal CaCl 2 and 0.1 molal $\mathrm{MgCl}_{2}$ solution. Note that brine $\mathrm{pH}$ values are conditional (c) because of the high ionic strength. 
electron microscopy with energy dispersive $\mathrm{x}$-ray spectroscopy (ESEM/EDX) and powder x-ray diffraction (XRD).

\section{Cement - Rock - Brine - $\mathrm{CO}_{2}$ Experiments}

Static Dickson-type Au reactors housed in water-filled pressure vessels were used to react cement, sandstone, shale, synthetic brine and supercritical $\mathrm{CO}_{2}$ at $95^{\circ} \mathrm{C}$ and $10 \mathrm{MPa}$. Specific weights of cement, sandstone, shale, and brine are listed in Table 2. Coherent sandstone or shale rock fragments were used in the experiments due to limited availability from core. We monitored reaction kinetics and the approach to equilibrium by sampling the solution as a function of time. The reactor setup allows sequential sampling of the aqueous phase while the experiment is at pressure and temperature. All metals measured in solution were from the rock-fluid interactions, because the supercritical $\mathrm{CO}_{2}$ and the brine contact only gold or passivated titanium. After one month of reaction, supercritical $\mathrm{CO}_{2}$ was injected into the gold bag and reacted for an additional month. About 20 grams of supercritical $\mathrm{CO}_{2}$ were added to the reaction vessel to ensure excess $\mathrm{CO}_{2}$ during the reaction. To add the $\mathrm{CO}_{2}$, liquid $\mathrm{CO}_{2}$ was pressurized above the run pressure and injected into the reaction vessel through the sample tube. The liquid $\mathrm{CO}_{2}$ transitions to supercritical $\mathrm{CO}_{2}$ at the run pressure and temperature. The amount of $\mathrm{CO}_{2}$ injected was estimated from change in volume of the liquid $\mathrm{CO}_{2}$. Several brine samples were taken and analyzed for solution chemistry over the duration of the experiment. At the end of the experiment, the reaction vessel was cooled to room temperature, excess $\mathrm{CO}_{2}$ was removed, and solid reactants were rinsed with distilled and deionized water several times to remove brine. The solids were dried at $60^{\circ} \mathrm{C}$ prior to XRD and ESEM/EDX analysis. Samples for dissolved $\mathrm{Al}, \mathrm{Ca}, \mathrm{Fe}, \mathrm{Mg}$, and $\mathrm{Si}$ analyses were filtered, and directly diluted with acidified distilled and deionized water (using high purity $\mathrm{HNO}_{3}$ ).

Samples for total dissolved inorganic carbon were injected directly into $1 \mathrm{~N} \mathrm{NaOH}$ to trap the $\mathrm{CO}_{2}$, filtered to remove any solids that precipitated, and analyzed for dissolved inorganic carbon, calcium, and magnesium. Total dissolved carbon should be equal to the measured inorganic carbon in the filtered sample plus the amount of carbon trapped as calcite minerals in the $\mathrm{NaOH}$ extraction. Comparison of results from the $\mathrm{NaOH}$ extraction with estimates from Duan and Sun (2003) caused us to question the viability of using the extraction technique to quantify dissolved carbon in the experiments. Although the median value of the dissolved carbon concentrations estimated from the extraction technique (0.78 molal) agrees with the theoretical prediction (0.69 molal), there is a significant amount of scatter in the extracted values over time (ranging from 1.12 to 0.53 molal). The scatter largely correlates to changes in measured dissolved calcium, because calcium is predicted to be trapped as $\mathrm{CaCO}_{3}$ solid rather than some mixture of $\mathrm{CaCO}_{3}+\mathrm{Ca}(\mathrm{OH})_{2}$ solids (any $\mathrm{Mg}$ is predicted to be trapped as $\mathrm{Mg}(\mathrm{OH})_{2}$ and was not considered in the $\mathrm{NaOH}$ extraction method). We have chosen to use the theoretical dissolved $\mathrm{CO}_{2}$ concentrations in the development of the geochemical model because of the uncertainty associated with the $\mathrm{NaOH}$ extraction chemistry. However, we report both the extraction and theoretical values, because caustic extractions are commonly used to quantify total dissolved $\mathrm{CO}_{2}$.

\section{Analysis}

Major and trace metals in the aqueous samples and the stock solution were analyzed using inductively coupled plasma mass spectroscopy (ICP-MS, Make/Model: Thermo Electron Corp/X Series Q-ICPMS). Samples were prepared volumetrically using an internal standard solution in $2 \%$ nitric acid. A fully quantitative analysis using a linear calibration curve based on known standards was performed. The internal standard was corrected for instrument drift and suppression from the sodium chloride matrix. Silica was run in collision cell technology (CCT) mode to avoid polyatomic interferences. Detection levels were established from duplicate blanks and serial dilution preparations. Matrix spike samples were analyzed for quality control. Detection limits were about $3,0.2,0.5,4$, and $0.35 \mathrm{ng} / \mathrm{g}$ for $\mathrm{Ca}, \mathrm{Mg}, \mathrm{Al}, \mathrm{Si}$, and Fe, respectively.

Total inorganic carbon (TIC) concentrations are determined using an automated OI Analytical Aurora 1030W Carbon Analyzer. The Aurora 1030W uses a

Table 2 Cement-Rock-Brine- $\mathrm{CO}_{2}$ Experiments

\begin{tabular}{|c|c|c|c|c|c|c|}
\hline ID & Cement (g) & Shale (g) & Sandstone (g) & Brine $(g)$ & Days reacted before $\mathrm{CO}_{2}$ & Days reacted after $\mathrm{CO}_{2}$ \\
\hline GBCO2_1 & 4.0 & & & 280.5 & 11 & 30 \\
\hline GBCO2_2 & 20.0 & & & 204.5 & 21 & 22 \\
\hline 7CO2 & & & 5.6 & 301.2 & 33 & 28 \\
\hline 14CO2 & & 6.4 & & 301.2 & 31 & 31 \\
\hline GB7CO2 & 4.8 & & 4.9 & 252.5 & 26 & 44 \\
\hline GB14CO2 & 8.6 & 8.7 & & 246.5 & 40 & 35 \\
\hline
\end{tabular}

All experiments were conducted in 1.8 molal $\mathrm{NaCl}, 0.55$ molal $\mathrm{CaCl}_{2}$ and 0.1 molal $\mathrm{MgCl}_{2}$ brine with 20 grams of supercritical $\mathrm{CO}_{2}$ at $95^{\circ} \mathrm{C}$ and $10 \mathrm{MPa}$. 
syringe pump to transfer samples and reagents to a temperature-controlled reaction chamber. TIC samples are reacted with $5 \%$ phosphoric acid to evolve $\mathrm{CO}_{2}$ gas purged by a stream of $\mathrm{N}_{2}$ gas and quantified using a NDIR detector.

Solid mineralogy was determined from data collected from random orientation powder samples with a Scintag PAD V instrument using a $\mathrm{Cu}-\mathrm{K} \alpha$ source at $45 \mathrm{kV}$ and $35 \mathrm{~mA}$ from $5^{\circ}$ to $70^{\circ} 2 \Theta$ in $0.02^{\circ}$ steps. XRD cannot detect amorphous solids or minerals that are present at less than 2 wt\%.

Unreacted and reacted samples were analyzed using a Quanta 200 Environmental Scanning Electron Microscope in low vacuum mode with EDX. Images were collected with secondary and backscatter detectors from pressures ranging from 0.23 to 0.90 torr and $20-25 \mathrm{kV}$. EDX was use to determine the local chemical composition of materials using at $20 \mathrm{kV}$ and $11 \mathrm{~mm}$ working distance. All analyses are semi-quantitative.

\section{Geochemical Modeling}

Solution compositions from the batch experiments were modeled using the PHREEQC 2.15.0 geochemical code [34], and the SUPCRT92 thermodynamic database [35] augmented by CEMDATA07v2 [36]. The CEMDATA provides Gibbs free energies, heat capacity, and volume data for cement phases as a function of temperature and pressure $[37,38]$. The standard state for minerals and pure water is unit activity, and for all aqueous species other than dissolved $\mathrm{CO}_{2}$ is unit activity in a hypothetical 1 molal solution referenced to infinite dilution at any pressure and temperature. The dissolved $\mathrm{CO}_{2}$ concentrations were calculated assuming equilibrium with $f_{\mathrm{CO} 2}$ estimated from $\mathrm{CO}_{2}$ equation of state at $10 \mathrm{MPa}$ [39]. No other mass balance reactions were corrected for pressure. This introduces an error of about $\pm 0.1 \log \mathrm{K}$. pH was estimated from the forward model simulations. The B-dot ion interaction model was used to approximate the non-ideal behavior of solutions at elevated ionic strength and temperature. The B-dot equation is an extended form of the Debye-Huckel equation and was used in this study because it can be applied to $\mathrm{NaCl}$ based solutions with high ionic strengths ( 3 molal) over a wide range of temperature. However, it is generally recognized that the Bdot equation becomes increasing less accurate at I > 0.5 molal. Despite these limitations, we chose to use B-dot equation to correction for species activity because the Pitzer equations are lacking for many elements at temperatures above $25^{\circ} \mathrm{C}$. The use of the B-dot equation typically yields brines with slightly higher solution $\mathrm{pH}(\approx 0.1 \mathrm{pH}$ units). The thermodynamic and kinetic inputs to the geochemical model for reaction of cement, sandstone and shale with $\mathrm{CO}_{2}$-rich $\mathrm{Na}-\mathrm{Ca}-\mathrm{Mg}$ chloride brines are shown in Tables 3, 4, 5, 6, and 7 .
Table 3 Mineral weight percents used in geochemical simulations

\begin{tabular}{ccc}
\hline Phase & Sandstone & Shale \\
\hline Albite & $1.5 \%$ & $2 \%$ \\
Chlorite & $6 \%$ & $30 \%$ \\
Dolomite & $0.5 \%$ & $0.75 \%$ \\
Illite & $1.5 \%$ & $44 \%$ \\
Kaolinite & $4 \%$ & $4 \%$ \\
Quartz & $86 \%$ & $20 \%$ \\
Siderite & $1.5 \%$ & $0.75 \%$ \\
\hline
\end{tabular}

(Ankerite was modeled as a 25 - 75 siderite-dolomite mixture for sandstone and a 50 - 50 siderite-dolomite mixture for the shale.)

All sandstone and shale reactions are assumed to be kinetically controlled and are modeled using

$$
r= \pm k A\left(1-\frac{L A P}{K_{s p}}\right)
$$

where $r$ is the dissolution or precipitation rate per unit time per unit area, $k$ is the kinetic rate constant, $A$ is the mineral surface area, IAP is the ion activity product, and $K_{s p}$ the solubility constant. Surface area is adjusted to fit the solution composition (Table 4). All of reactive surface area was assumed to be available for reaction for the sandstone experiments, whereas only 10 percent of the shale reactive surface area was assumed to participate in reactions. The rate constant for $\mathrm{Fe}(\mathrm{OH})_{3}$ precipitation in the sandstone experiments was fitted to the solution composition and is normalized the mineral moles (Table 7). All other rate constants are from Palandri and Kharaka [40] (Table 6):

$$
k=k_{25}^{n u} \exp \left(\frac{-E_{a}^{n u}}{R}\left(\frac{1}{T}-\frac{1}{298.15}\right)\right)+k_{25}^{H} \exp \left(\frac{-E_{a}^{H}}{R}\left(\frac{1}{T}-\frac{1}{298.15}\right)\right)\{H+\}^{n}
$$

where $R$ is the universal gas constant, $T$ the absolute temperature, $\left\{\mathrm{H}^{+}\right\}$the activity of the hydrogen ion, $n$ an exponential factor, and $k_{25}{ }^{n u}$ and $k_{25}{ }^{H}$ the neutral and acid rate constants at $25^{\circ} \mathrm{C}$ and $E_{\mathrm{a}}{ }^{n u}$ and $E_{\mathrm{a}}{ }^{H}$ the neutral and acid activation energies, respectively.

Table 4 Surface areas used in the modeling calculations

\begin{tabular}{ccc}
\hline Phase & \multicolumn{2}{c}{$\begin{array}{c}\text { Surface Area } \\
\left(\mathbf{c m}^{\mathbf{2}} \mathbf{g}\right)\end{array}$} \\
& Shale & Sandstone \\
\hline Boehmite & 0.02 & 0 \\
Smectite & 9505 & 317.7 \\
Ripidolite & 224.2 & 87.9 \\
Dolomite & 0.5 & 1.0 \\
Illite & 9505 & 317.7 \\
Kaolinite & 18.3 & 17.9 \\
Low-albite & 45.3 & 33.4 \\
Quartz & 9.1 & 39.1 \\
Siderite & 0.4 & 2.2 \\
\hline
\end{tabular}


Table 5 Geochemical model for reaction of cement, sandstone and shale with $\mathrm{CO}_{2}$ and $\mathrm{Na}, \mathrm{Ca}$, $\mathrm{Mg}$ chloride brines

\begin{tabular}{|c|c|c|c|}
\hline \multicolumn{4}{|c|}{ Cement Hydration } \\
\hline Phase & Mass Balance & $\log \mathrm{K} 95^{\circ} \mathrm{C}$ & $\log \mathrm{SI} 95^{\circ} \mathrm{C}$ \\
\hline Portlandite & $\mathrm{Ca}(\mathrm{OH})_{2}+2 \mathrm{H}^{+} \Leftrightarrow \mathrm{Ca}^{2+}+2 \mathrm{H}_{2} \mathrm{O}$ & 18.30 & $0.04 \pm 0.04$ \\
\hline Psuedowollastonite & $\mathrm{CaSiO}_{3}+2 \mathrm{H}^{+} \Leftrightarrow \mathrm{SiO}_{2}+\mathrm{Ca}^{2+}+\mathrm{H}_{2} \mathrm{O}$ & 10.97 & $0.3 \pm 1.3$ \\
\hline Brucite & $\mathrm{Mg}(\mathrm{OH})_{2}+2 \mathrm{H}^{+} \Leftrightarrow \mathrm{Mg}^{2+}+2 \mathrm{H}_{2} \mathrm{O}$ & 12.65 & $0.7 \pm 0.1$ \\
\hline${ }^{1}$ Hydrotalcite & $\mathrm{Mg}_{4} \mathrm{Al}_{2} \mathrm{O}_{7}(\mathrm{OH})_{2}: 10 \mathrm{H}_{2} \mathrm{O}+14 \mathrm{H}^{+} \Leftrightarrow 2 \mathrm{Al}^{3+}+4 \mathrm{Mg}^{2+}+17 \mathrm{H}_{2} \mathrm{O}$ & 53.67 & $2.8 \pm 0.2$ \\
\hline${ }^{1} \mathrm{Fe}-\mathrm{Hydrogarnet}$ & $\mathrm{Ca}_{3} \mathrm{Fe}_{2}(\mathrm{OH})_{12}+12 \mathrm{H}^{+} \Leftrightarrow 3 \mathrm{Ca}^{2+}+2 \mathrm{Fe}^{3+}+12 \mathrm{H}_{2} \mathrm{O}$ & 68.50 & $-3.4 \pm 2.7$ \\
\hline Anhydrite & $\mathrm{CaSO}_{4} \Leftrightarrow \mathrm{Ca}^{2+}+\mathrm{SO}_{4}^{2-}$ & -5.08 & $-0.3 \pm 0.1$ \\
\hline \multicolumn{4}{|c|}{ Cement, Sandstone, and Shale Carbonation } \\
\hline Phase & \multicolumn{2}{|c|}{ Mass Balance } & $\log \mathrm{K} 95^{\circ} \mathrm{C}$ \\
\hline Albite & \multicolumn{2}{|c|}{$\mathrm{NaAlSi}_{3} \mathrm{O}_{8}+4 \mathrm{H}^{+} \Leftrightarrow \mathrm{Al}^{3+}+\mathrm{Na}^{+}+2 \mathrm{H}_{2} \mathrm{O}+3 \mathrm{SiO}_{2}$} & 0.46 \\
\hline${ }^{1}$ Amorphous $\mathrm{Al}(\mathrm{OH})_{3}$ & \multicolumn{2}{|c|}{$\mathrm{Al}(\mathrm{OH})_{3}+3 \mathrm{H}^{+} \Leftrightarrow \mathrm{Al}^{3+}+3 \mathrm{H}_{2} \mathrm{O}$} & 5.42 \\
\hline${ }^{1}$ Amorphous $\mathrm{Fe}(\mathrm{OH})_{3}$ & \multicolumn{2}{|l|}{$\mathrm{Fe}(\mathrm{OH})_{3}+3 \mathrm{H}^{+} \Leftrightarrow \mathrm{Fe}^{3+}+3 \mathrm{H}_{2} \mathrm{O}$} & 2.86 \\
\hline Boehmite & \multicolumn{2}{|l|}{$\mathrm{AlO}(\mathrm{OH})+3 \mathrm{H}^{+} \Leftrightarrow \mathrm{Al}^{3+}+2 \mathrm{H}_{2} \mathrm{O}$} & 3.75 \\
\hline Calcite & \multicolumn{2}{|l|}{$\mathrm{CaCO}_{3}+\mathrm{H}^{+} \Leftrightarrow \mathrm{Ca}^{2+}+\mathrm{HCO}_{3}^{-}$} & 0.85 \\
\hline Chalcedony & \multicolumn{2}{|c|}{$\mathrm{SiO}_{2} \Leftrightarrow \mathrm{SiO}_{2, \mathrm{aq}}$} & -2.88 \\
\hline Dolomite & \multicolumn{2}{|l|}{$\mathrm{CaMg}\left(\mathrm{CO}_{3}\right)_{2}+2 \mathrm{H}^{+} \Leftrightarrow \mathrm{Ca}^{2+}+\mathrm{Mg}^{2+}+2 \mathrm{HCO}_{3}^{-}$} & 1.41 \\
\hline Ripedolite $14 \AA$ & \multicolumn{2}{|c|}{$\mathrm{Mg}_{3} \mathrm{Fe}_{2} \mathrm{Al}_{2} \mathrm{Si}_{3} \mathrm{O}_{10}(\mathrm{OH})_{8}+16 \mathrm{H}^{+} \Leftrightarrow 2 \mathrm{Al}^{3+}+3 \mathrm{SiO}_{2, \mathrm{aq}}+3 \mathrm{Mg}^{2+}+2 \mathrm{Fe}^{2+}+12 \mathrm{H}_{2} \mathrm{O}$} & 41.45 \\
\hline Illite & \multicolumn{2}{|c|}{$\mathrm{K}_{0.6} \mathrm{Mg}_{0.25} \mathrm{Al}_{2.3} \mathrm{Si}_{3.5} \mathrm{O}_{10}(\mathrm{OH})_{2}+8 \mathrm{H}^{+} \Leftrightarrow 0.25 \mathrm{Mg}^{2+}+0.6 \mathrm{~K}^{+}+2.3 \mathrm{Al}^{3+}+3.5 \mathrm{SiO}_{2}+5 \mathrm{H}_{2} \mathrm{O}$} & 2.56 \\
\hline Kaolinite & \multicolumn{2}{|c|}{$\mathrm{Al}_{2} \mathrm{Si}_{2} \mathrm{O}_{5}(\mathrm{OH})_{4}+6 \mathrm{H}^{+} \Leftrightarrow 2 \mathrm{Al}^{3+}+2 \mathrm{SiO}_{2}+5 \mathrm{H}_{2} \mathrm{O}$} & 1.35 \\
\hline Magnesite & \multicolumn{2}{|c|}{$\mathrm{MgCO}_{3}+\mathrm{H}^{+} \Leftrightarrow \mathrm{Mg}^{2+}+\mathrm{HCO}_{3}^{-}$} & 0.71 \\
\hline Quartz & \multicolumn{2}{|l|}{$\mathrm{SiO}_{2} \Leftrightarrow \mathrm{SiO}_{2, \mathrm{aq}}$} & -3.10 \\
\hline Siderite & \multicolumn{2}{|l|}{$\mathrm{FeCO}_{3}+\mathrm{H}^{+} \Leftrightarrow \mathrm{Fe}^{2+}+\mathrm{HCO}_{3}^{-}$} & -1.40 \\
\hline $\begin{array}{c}\text { Smectite } \\
\text { (Ca-Beidellite) }\end{array}$ & \multicolumn{2}{|c|}{$\mathrm{Ca}_{0.165} \mathrm{Al}_{2.33} \mathrm{Si}_{3.67} \mathrm{O}_{10}(\mathrm{OH})_{2}+7.32 \mathrm{H}^{+} \Leftrightarrow+0.165 \mathrm{Ca}^{2+}+2.33 \mathrm{Al}^{3+}+4.66 \mathrm{H}_{2} \mathrm{O}+3.67 \mathrm{SiO}_{2}$} & -0.62 \\
\hline
\end{tabular}

Unless otherwise noted the values are estimated from SUPCRT92 [35]; ${ }^{1}$ values from CEMDATA [36].

A few additional constraints to the geochemical model were needed to match $\mathrm{Al}, \mathrm{Fe}$, and $\mathrm{Si}$ solution chemistry and involve the precipitation of secondary phases. We added dissolved $\mathrm{O}_{2}$ to account for the attenuation of the initial spike in Fe in the sandstone experiment as secondary precipitation of $\mathrm{Fe}(\mathrm{OH})_{3}$. Quartz precipitation is suppressed and dissolved Si concentrations are limited by chalcedony equilibrium with no kinetic controls. Smectite precipitation is tied to illite surface area and is modeled as Ca-beidellite, $\mathrm{Ca}_{0.165} \mathrm{Al}_{2.33} \mathrm{Si}_{3.67} \mathrm{O}_{10}(\mathrm{OH})_{2}$. Boehmite, $\mathrm{AlO}(\mathrm{OH})$, precipitation is suppressed until the solution is slightly supersaturated $(\log \mathrm{SI}=1)$. Uptake of $\mathrm{Fe}(\mathrm{II})$ during cement carbonation is modeled as an ideal continuous $\mathrm{FeCO}_{3}-\mathrm{CaCO}_{3}$ solid solution. No other solid solutions are included in this model. We model cement carbonation from an assemblage of portlandite, psuedowollastonite, brucite, hydrotalcite, Fe-hydrogarnet, and anhydrite estimated from the hydration of initial

Table 6 Rate parameters from Palandri and Kharaka [40]

\begin{tabular}{|c|c|c|c|c|c|c|c|c|}
\hline \multirow[t]{2}{*}{ Phase } & \multicolumn{2}{|c|}{ Neutral } & \multicolumn{3}{|c|}{ Acid } & \multicolumn{3}{|c|}{ Base } \\
\hline & $\mathrm{k}_{25^{\circ} \mathrm{C}}\left(\mathrm{mol} / \mathrm{m}^{2} / \mathrm{s}\right)$ & $E_{a}(\mathrm{~mol} / \mathrm{KJ})$ & $\mathrm{k}_{25^{\circ} \mathrm{C}}\left(\mathrm{mol} / \mathrm{m}^{2} / \mathrm{s}\right)$ & $E_{a}(\mathrm{~mol} / \mathrm{KJ})$ & $\mathrm{N}$ & $\mathrm{k}_{25^{\circ} \mathrm{C}}\left(\mathrm{mol} / \mathrm{m}^{2} / \mathrm{s}\right)$ & $\mathrm{E}_{\mathrm{a}}(\mathrm{mol} / \mathrm{KJ})$ & $\mathbf{n}$ \\
\hline${ }^{a}$ Boehmite & -11.5 & 61.2 & -7.7 & 47.5 & 0.99 & -16.7 & 80.1 & -0.78 \\
\hline $\begin{array}{l}\text { Dolomite } \\
{ }^{\mathrm{b}} \mathrm{Fe}(\mathrm{OH})_{3}\end{array}$ & -7.5 & 52.2 & -3.2 & 36.1 & 0.50 & & & \\
\hline Ripedolite & -12.5 & 88 & -11.1 & 88.0 & 0.50 & & & \\
\hline Illite & -12.8 & 35 & -11.0 & 23.6 & 0.34 & -16.5 & 58.9 & -0.40 \\
\hline Kaolinite & -13.2 & 22.2 & -11.3 & 65.9 & 0.78 & -17.0 & 17.9 & -0.47 \\
\hline Low-albite & -12.6 & 69.8 & -10.2 & 65.0 & 0.46 & -15.6 & 71.0 & -0.57 \\
\hline Quartz & -14.0 & 87.7 & & & & & & \\
\hline Siderite & -8.9 & 62.76 & -3.8 & 45.0 & 0.90 & & & \\
\hline Smectite & -12.8 & 35 & -11.0 & 23.6 & 0.34 & -16.5 & 58.9 & -0.40 \\
\hline
\end{tabular}

${ }^{a}$ Gibbsite dissolution rates were applied for boehmite. ${ }^{b} \mathrm{Fe}(\mathrm{OH})_{3}$ rate was estimated from match to the solution chemistry normalized to mineral moles and is listed in Table 7. 
Table 7 Conditional rate constants for the cement phases estimated from fits of the solution composition and anhydrous cement composition for each experiment

\begin{tabular}{|c|c|c|}
\hline Phase & Experiment & $\log \mathrm{k}(\mathrm{mol} / \mathrm{s} / \mathrm{mol}-\mathrm{mineral})$ \\
\hline \multirow[t]{4}{*}{ Anhydrite } & ${ }^{a}$ Cement:Brine & -6.2 \\
\hline & ${ }^{\mathrm{b}}$ Cement:Brine & -7.3 \\
\hline & Sandstone \pm cement & -6.3 \\
\hline & Shale \pm cement & -6.9 \\
\hline \multirow[t]{4}{*}{ Hydrogarnet-Fe } & ${ }^{\mathrm{a} C e m e n t: B r i n e}$ & -6.2 \\
\hline & ${ }^{\mathrm{b}}$ Cement:Brine & -7.3 \\
\hline & Sandstone \pm cement & -6.3 \\
\hline & Shale \pm cement & -6.9 \\
\hline \multirow[t]{4}{*}{ Hydrotalcite } & ${ }^{\mathrm{a} C e m e n t: B r i n e}$ & -5.5 \\
\hline & ${ }^{\mathrm{b}}$ Cement:Brine & -6.6 \\
\hline & Sandstone \pm cement & -5.6 \\
\hline & Shale \pm cement & -6.2 \\
\hline \multirow[t]{4}{*}{ Brucite } & ${ }^{\mathrm{a} C e m e n t: B r i n e}$ & -5.5 \\
\hline & ${ }^{\mathrm{b}}$ Cement:Brine & -6.6 \\
\hline & Sandstone \pm cement & -5.6 \\
\hline & Shale \pm cement & -6.2 \\
\hline \multirow[t]{4}{*}{ Portlandite } & ${ }^{\mathrm{a} C e m e n t: B r i n e}$ & -5.5 \\
\hline & ${ }^{\mathrm{b}}$ Cement:Brine & -6.6 \\
\hline & Sandstone \pm cement & -5.6 \\
\hline & Shale \pm cement & -6.2 \\
\hline \multirow[t]{4}{*}{ Pseudowollastonite } & ${ }^{\mathrm{a} C e m e n t: B r i n e}$ & -6.2 \\
\hline & ${ }^{\mathrm{b}}$ Cement:Brine & -7.3 \\
\hline & Sandstone \pm cement & -6.3 \\
\hline & Shale \pm cement & -6.9 \\
\hline Amorphous $\mathrm{Fe}(\mathrm{OH})_{3}$ & Sandstone & -8.6 \\
\hline Calcite & ${ }^{\mathrm{b}}$ Cement:Brine & -8.0 \\
\hline Calcite & Shale \pm cement & -7.0 \\
\hline $\mathrm{FeCO}_{3}$ & Shale \pm cement & -10.0 \\
\hline
\end{tabular}

The range in values reflects incomplete hydration and diffusion-controlled

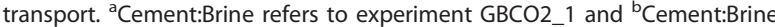
refers to experiment $\mathrm{GBCO} 2$ 22.

anhydrous cement composition using the experimental cement to brine ratios (Table 2). We use pseudowollastonite to represent the amorphous hydrated calcium silicate ("CSH") because its solubility is consistent with our experimental measurements. Brucite and hydrotalcite were needed to account for the observed removal of $\mathrm{Mg}$ from the brine during cement hydration and its enhanced solubility during carbonation, even though these phases were not identified in the XRD pattern. Attempts to model the poorly crystalline phase as $\mathrm{Mg}-\mathrm{Ca}$ silica hydrate introduced excessive amounts of dissolved silica. Anhydrite accounts for the sulfate noted in the anhydrous components.

Carbonation of the hydrated mineral assemblage was modeled with calcite, amorphous $\mathrm{SiO}_{2}$ (as chalcedony), $\mathrm{Fe}(\mathrm{OH})_{3}$, and boehmite for cement: brine $<1: 50$ or amorphous $\mathrm{Al}(\mathrm{OH})_{3}$ for cement: brine $>1: 25$ (Table 2). Fitted rate constants for the cement phases reflect the varied extent of cement hydration and carbonation in each experiment and are normalized to mineral moles (Table 7). It is important to note that the fitted reaction rates are conditional to these experiments and likely represent diffusion of the reactants into the cement, which had a tendency to solidify at the bottom of the reaction vessel even though the experiments were rocked.

\section{Model Uncertainty}

It is important to note that the lithology and cement geochemical models represent possible realizations of the dominant geochemical reactions. The non-uniqueness of the lithology model reflects the wide range of minerals that can be used to describe major element chemistry and was made apparent in our efforts to fit the dissolved $\mathrm{Si}$ prior to the injection of $\mathrm{CO}_{2}$ in the sandstone experiment. The best matches required either using unrealistically high illite in the sandstone (higher than in the shale) or alternatively excessive high quartz surface areas (which were also higher than in the shale). Presumably, some combination of aluminosilicate dissolution and enhanced quartz dissolution (in the sandstone) is responsible for the $\mathrm{Si}$ accumulation prior to $\mathrm{CO}_{2}$ injection. Compositional variations among carbonates, chlorite, and illite could not be considered owing to a lack of thermodynamic data. Additionally, phases such as boehmite or Fe $(\mathrm{OH})_{3}$ represent idealizations of aluminum- or ferric oxyhydroxides that may, in reality, may be characterized by different stoichiometries or crystal structure than those phases represented in the thermodynamic database.

A significant number of factors contribute to the uncertainty in the cement carbonation geochemical model. Mineralogy, including the pertinent stoichiometry and equilibrium constants, of the hydrated cement is poorly constrained by the experimental data. Moreover, the mineralogical sink for magnesium is unconstrained and may or may not be associated with the CSH phase. Solid solutions may be important for a number of phases in the hydrated cement and carbonated mineral datasets as well as in the reservoir lithology. We employ either pure phase or ideal solid solution because data to constrain non-ideal solid solutions are lacking.

\section{Experimental Results}

\section{Cement Hydration at 95 and $115^{\circ} \mathrm{C}$}

Cement hydration with reservoir brines altered both the brine chemistry and the hydrated cement phases in experiments at 95 and $115^{\circ} \mathrm{C}$ (Table 8). Our results show that when Class $\mathrm{G}$ cement reacts with distilled water or 0.13 molal $\mathrm{CaCl}_{2}$ brine, the water composition is largely controlled by the solubility of portlandite and an amorphous calcium silica hydrate $(\mathrm{CSH})$. Portlandite was identified as the only crystalline phase by XRD. ESEM analysis also showed crystalline portlandite, as well as an 
Table 8 Measured solution composition for cement hydration and the experiment end

\begin{tabular}{|c|c|c|c|c|c|c|c|c|c|}
\hline ID & $\begin{array}{c}\text { Al } \\
\text { molal }\end{array}$ & $\begin{array}{c}\mathrm{Ca} \\
\text { molal }\end{array}$ & $\begin{array}{c}\mathrm{Fe} \\
\text { molal }\end{array}$ & $\begin{array}{c}\mathrm{Mg} \\
\text { molal }\end{array}$ & $\begin{array}{c}\mathrm{Si} \\
\text { molal }\end{array}$ & $\begin{array}{c}\mathrm{F}^{-} \\
\text {molal }\end{array}$ & $\begin{array}{c}\mathrm{Cl}^{-} \\
\text {molal }\end{array}$ & $\begin{array}{l}\mathrm{NO}_{3}^{-} \\
\text {molal }\end{array}$ & $\begin{array}{l}\mathrm{SO}_{4}{ }^{2-} \\
\text { molal }\end{array}$ \\
\hline G3 & 1.39E-05 & 0.109 & $3.68 \mathrm{E}-07$ & ND & 1.73E-05 & & & & \\
\hline G6 & 1.91E-05 & $4.68 \mathrm{E}-01$ & $9.64 \mathrm{E}-07$ & $1.34 \mathrm{E}-05$ & 4.87E-06 & & & & \\
\hline G7 & 1.70E-05 & 7.83E-03 & 1.07E-07 & ND & 8.53E-06 & $5.86 \mathrm{E}-05$ & $1.73 \mathrm{E}-05$ & 2.38E-05 & $1.81 \mathrm{E}-03$ \\
\hline G8 & 1.89E-05 & $6.62 \mathrm{E}-03$ & 2.21E-07 & ND & 3.99E-05 & $6.01 \mathrm{E}-05$ & 1.66E-04 & $2.21 \mathrm{E}-05$ & 1.77E-03 \\
\hline G9 & 3.30E-05 & 4.42E-03 & 6.30E-08 & ND & 9.89E-06 & 8.06E-05 & $1.54 \mathrm{E}-05$ & 2.91E-05 & $3.64 \mathrm{E}-03$ \\
\hline G10 & 2.76E-05 & 6.01E-03 & 7.99E-08 & ND & 3.44E-05 & $1.21 \mathrm{E}-04$ & 2.30E-05 & 2.60E-05 & 3.85E-03 \\
\hline G11 & 2.05E-05 & $7.82 \mathrm{E}-03$ & 7.30E-08 & ND & $3.30 \mathrm{E}-05$ & 5.51E-05 & 2.42E-05 & 2.43E-05 & 2.33E-03 \\
\hline G12 & $4.22 \mathrm{E}-05$ & 5.74E-03 & $6.89 \mathrm{E}-08$ & ND & 8.56E-06 & 7.06E-05 & 1.93E-05 & $2.59 \mathrm{E}-05$ & 4.10E-03 \\
\hline G13 & $3.12 \mathrm{E}-05$ & 5.90E-03 & 7.43E-08 & ND & 5.31E-05 & $6.96 \mathrm{E}-05$ & 3.89E-05 & 2.77E-05 & 4.85E-03 \\
\hline G14 & 3.05E-06 & 5.88E-01 & 1.46E-06 & 5.41E-06 & 1.89E-07 & & 2.97 & & \\
\hline G15 & 3.35E-06 & $5.82 \mathrm{E}-01$ & 1.38E-06 & 5.95E-06 & $2.05 \mathrm{E}-07$ & & 3.00 & & \\
\hline
\end{tabular}

Blank values indicate that the ions were not measured. ND indicates concentrations were below detection.

amorphous calcium silicate, which we assume to be CSH (Figure 1).

The storage reservoir brine is likely to be distinct from the dilute waters used to mix the cement prior to injection in the well. The experiments in synthetic brine show that mineral assemblage at the cement - brine interface will be different than in the interior of the cement. The primary difference is that $\mathrm{Mg}$ has a very low solubility when the brine reacts with the anhydrous cement. Cement hydration produced a less alkaline and $\mathrm{Mg}$-poor brine $\left(\mathrm{Mg}=10^{-5} \mathrm{molal}\right)$. Although the solution was supersaturated with respect to brucite, $\mathrm{Mg}(\mathrm{OH})_{2}$, the resulting $\mathrm{Mg}$-bearing phase was poorly crystalline and could not be identified by XRD.
There is a large amount of uncertainty associated with the identification of stable or metastable cement minerals in the wellbore environment, because cements can range in composition and are often amorphous. Possible cement phases include anhydrous belite $\left(\mathrm{Ca}_{2} \mathrm{SiO}_{4}\right)$ which was present as a residual reactant in most of the experiments, and $\mathrm{CSH}$ phases such as hillebrandite $\left(\mathrm{Ca}_{2} \mathrm{SiO}_{3}(\mathrm{OH})_{2}{ }^{*} 0.17 \mathrm{H}_{2} \mathrm{O}\right)$, jennite $\left(\mathrm{Ca}_{1.67} \mathrm{SiO}_{2}(\mathrm{OH})_{3.33}\right.$ : $\left.0.43 \mathrm{H}_{2} \mathrm{O}\right)$, and tobermorite- $\mathrm{CSH}\left(\mathrm{Ca}_{0.83} \mathrm{SiO}_{2}(\mathrm{OH})\right.$ $\left.1.7^{*} 0.5 \mathrm{H}_{2} \mathrm{O}\right)$. Average ion activity products calculated from the solution chemistry at 95 and $115^{\circ} \mathrm{C}$ are listed in Table 9. It is likely that cements will alter to crystalline phases with time, because the transformation from amorphous to stable phases has been observed at $150^{\circ} \mathrm{C}$

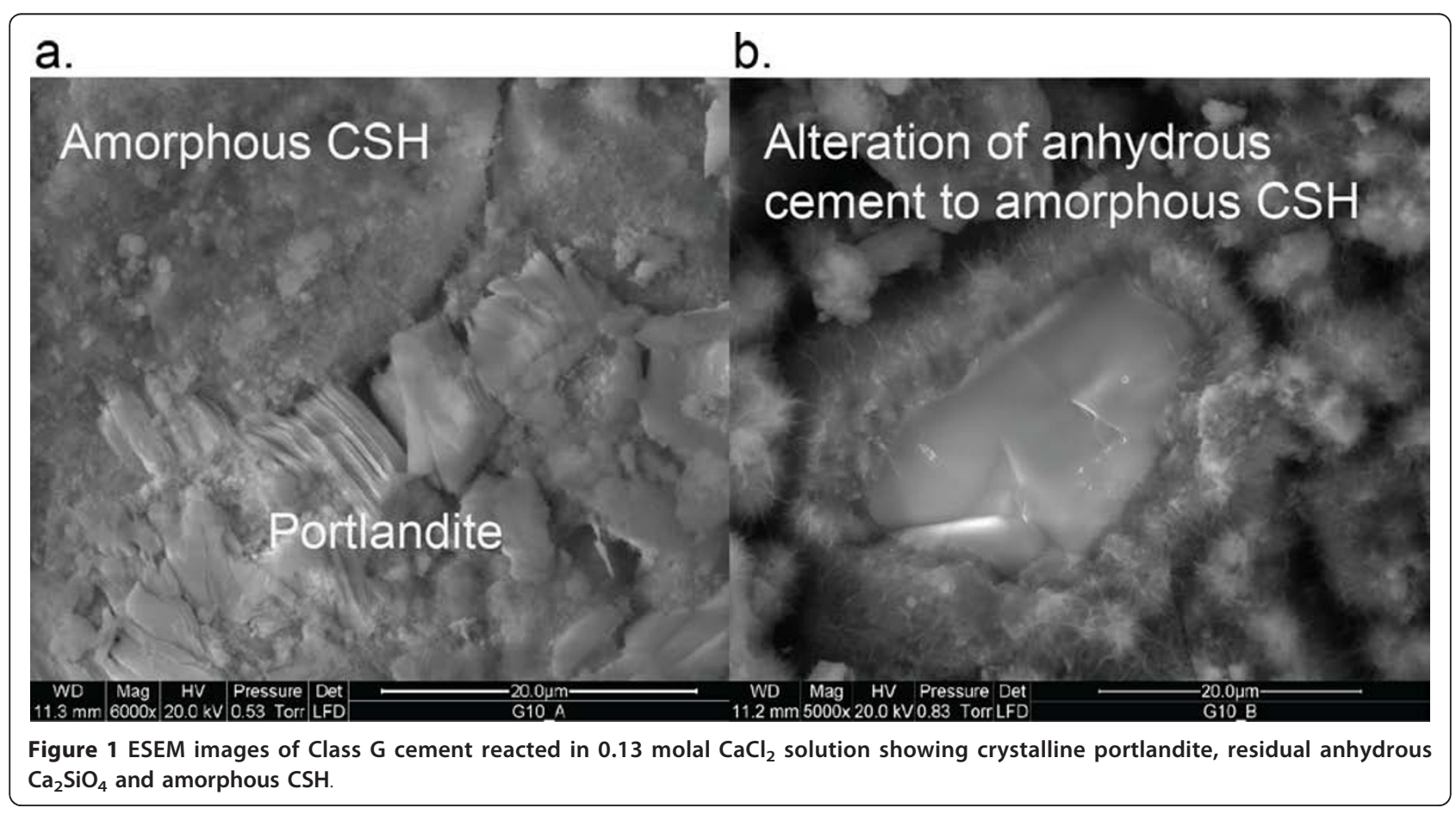




\begin{tabular}{cccc}
\hline Phase & Mass Balance & Log IAP 95 & Log IAP 115 \\
\hline Belite & $\mathrm{Ca}_{2} \mathrm{SiO}_{4}+4 \mathrm{H}^{+}=2 \mathrm{Ca}^{2+}+\mathrm{SiO}_{2}(\mathrm{aq})+2 \mathrm{H}_{2} \mathrm{O}$ & $29.6 \pm 1.2$ & $28.9 \pm 0.4$ \\
Hillibrandite & $\mathrm{Ca}_{2} \mathrm{SiO}_{3}(\mathrm{OH})_{2}{ }_{2}^{*} \mathrm{O}_{2} 2 \mathrm{H}_{2} \mathrm{O}+4 \mathrm{H}^{+}=2 \mathrm{Ca}^{2+}+\mathrm{SiO}_{2}(\mathrm{aq})+3.2 \mathrm{H}_{2} \mathrm{O}$ & $29.6 \pm 1.2$ & $28.9 \pm 0.4$ \\
Jennite $-\mathrm{CSH}$ & $\mathrm{Ca}_{1.67} \mathrm{SiO}_{2}(\mathrm{OH})_{3.33}: 0.43 \mathrm{H}_{2} \mathrm{O}+3.33 \mathrm{H}^{+}=1.67 \mathrm{Ca}^{2+}+\mathrm{SiO}_{2}(\mathrm{aq})+3.76 \mathrm{H}_{2} \mathrm{O}$ & $27.8 \pm 1.4$ & $27.3 \pm 0.5$ \\
Tobermorite & $\mathrm{Ca}_{0.83} \mathrm{SiO}_{2}(\mathrm{OH})_{1.7}{ }^{*} 0.5 \mathrm{H}_{2} \mathrm{O}+1.66 \mathrm{H}^{+}=0.83 \mathrm{Ca} 2++\mathrm{SiO}_{2}(\mathrm{aq})+2.2 \mathrm{H}_{2} \mathrm{O}$ & $11.7 \pm 0.7$ & $11.1 \pm 0.5$ \\
Pseudowollastonite & $\mathrm{CaSiO}_{3}+2 \mathrm{H}^{+} \Leftrightarrow \mathrm{SiO}_{2}+\mathrm{Ca}^{2+}+\mathrm{H}_{2} \mathrm{O}$ & $11.3 \pm 1.3$ & $11.5 \pm 0.5$ \\
\hline
\end{tabular}

for tobermorite [41]. Given the amorphous nature of $\mathrm{CSH}$ in our experiments, we have chosen to model it as psuedowollastonite $\left(\mathrm{CaSiO}_{3}\right)$ because measured solution compositions are near psuedowollastonite equilibrium (Table 5).

\section{Cement - Rock - Brine - $\mathrm{CO}_{2}$ Experiments}

In this section we describe the experimental results from the reaction of supercritical $\mathrm{CO}_{2}$ and synthetic brine with reservoir rock, cap rock, and wellbore cement. The sandstone and shale used in the experiments are meant to represent storage reservoir and the cap rock respectively (although the materials themselves are from the heterolithic sandstone and shale unit that forms the upper section of the carbon storage reservoir at the Krechba Field, In Salah, Algeria). Interpretation of the rate and solubility controlling reactions will be discussed in Geochemical Model.

Sandstone - brine - $\mathrm{CO}_{2}$

The sandstone consists of tightly carbonate-cemented quartz grains with about 7 wt \% chlorite lining the pores [33]. Figures 2 and 3 show the solution profiles with time and images of the unreacted and reacted sandstone. Reaction of sandstone with brine produced a fairly neutral solution with low dissolved $\mathrm{CO}_{2}$, dissolved $\mathrm{Ca}$ and $\mathrm{Mg}$ near the initial brine concentrations, dissolved $\mathrm{Si}$ and Fe that increased slowly with time, and very low dissolved $\mathrm{Al}$. Injection of supercritical $\mathrm{CO}_{2}$ into the reaction vessel resulted in marked increases in dissolved $\mathrm{CO}_{2}, \mathrm{Si}$, and Fe. Dissolved $\mathrm{CO}_{2}$ and $\mathrm{Si}$ increase rapidly to a constant concentration. Dissolved Fe peaked upon injection of $\mathrm{CO}_{2}$, dropped to a minimum value and then increased linearly with time. No abrupt changes were observed in dissolved $\mathrm{Ca}, \mathrm{Mg}$, or $\mathrm{Al}$.

Secondary precipitates were either amorphous to XRD or present in amounts below the XRD detection limit for crystalline phases to be identified. ESEM images show relatively large amounts of silica and iron precipitates as well as thin hexagonal sheet silicates (Figure 3). It is not possible to identify the composition with EDX because the beam samples an area larger than the surface precipitates. It is also possible that the precipitates formed as the solution was cooled prior to taking apart the reaction vessel and recovering the solids for analysis.
Shale - brine - $\mathrm{CO}_{2}$

Figures 4 and 5 show the solution profiles with time and images of the unreacted and reacted shale. Similar to the sandstone experiment, reaction of shale with brine produced a fairly neutral solution with low dissolved $\mathrm{CO}_{2}$, dissolved $\mathrm{Ca}$ and $\mathrm{Mg}$ near the initial brine composition, dissolved $\mathrm{Si}$ that increased slowly, and very low dissolved $\mathrm{Fe}$ and $\mathrm{Al}$. Injection of supercritical $\mathrm{CO}_{2}$ into the reaction vessel produced a marked increase in dissolved $\mathrm{CO}_{2}, \mathrm{Si}, \mathrm{Fe}$, and $\mathrm{Al}$, with no change in the dissolved $\mathrm{Ca}$ and $\mathrm{Mg}$.

We see very little indication of alteration of the shale by $\mathrm{CO}_{2}$-rich brines at the experiment end by ESEM/ EDX analysis (Figure 5). We detect only small precipitates on the shale surface and in the suspension, which may have formed when the sample was quenched from $95^{\circ} \mathrm{C}$ to room temperature. Particle size was too small to confirm the chemical composition with EDX.

Cement - brine - $\mathrm{CO}_{2}$

Cement altered to aragonite, calcite, and amorphous silica by the $\mathrm{CO}_{2}$-rich brines. XRD analyses show aragonite, calcite, and residual anhydrous $\mathrm{Ca}_{2} \mathrm{SiO}_{3}$. We assume that $\mathrm{Si}$ from the $\mathrm{CSH}$ phase was altered to amorphous silica. Figures 6 and 7 show the change in solution composition for the reaction of cement, brine, and supercritical $\mathrm{CO}_{2}$ at $95^{\circ} \mathrm{C}$ and $10 \mathrm{MPa}$ as solution $\mathrm{pH}\left(95^{\circ} \mathrm{C}\right)$, total dissolved $\mathrm{CO}_{2}, \mathrm{Ca}, \mathrm{Mg}, \mathrm{Si}, \mathrm{Fe}$, and $\mathrm{Al}$. These experiments had solid to brine ratios of 1:68 and 1:10 on $\mathrm{g} / \mathrm{g}$ basis. Trends in dissolved $\mathrm{Ca}$ and Mg suggest that starting materials may not have been fully hydrated prior to the injection of $\mathrm{CO}_{2}$. Extrapolation of the linear decrease in $\mathrm{Mg}$ to values measured in the solubility experiments, suggest that the cements would fully equilibrate with the brine within 20 days of reaction at $95^{\circ} \mathrm{C}$. The lack of complete hydration is of little consequence because the cement system is very reactive in brines with supercritical $\mathrm{CO}_{2}$. Upon injection of supercritical $\mathrm{CO}_{2}$, there was a marked increase in dissolved $\mathrm{CO}_{2}$, dissolved $\mathrm{Ca}$ decreased, dissolved $\mathrm{Mg}$ increased toward their initial brine concentration, dissolved $\mathrm{Si}$ increased to a constant value, and dissolved Fe and $\mathrm{Al}$ were quite low.

Experiments with higher amounts of cement resulted in solidification of cement at the bottom of the reactor. 


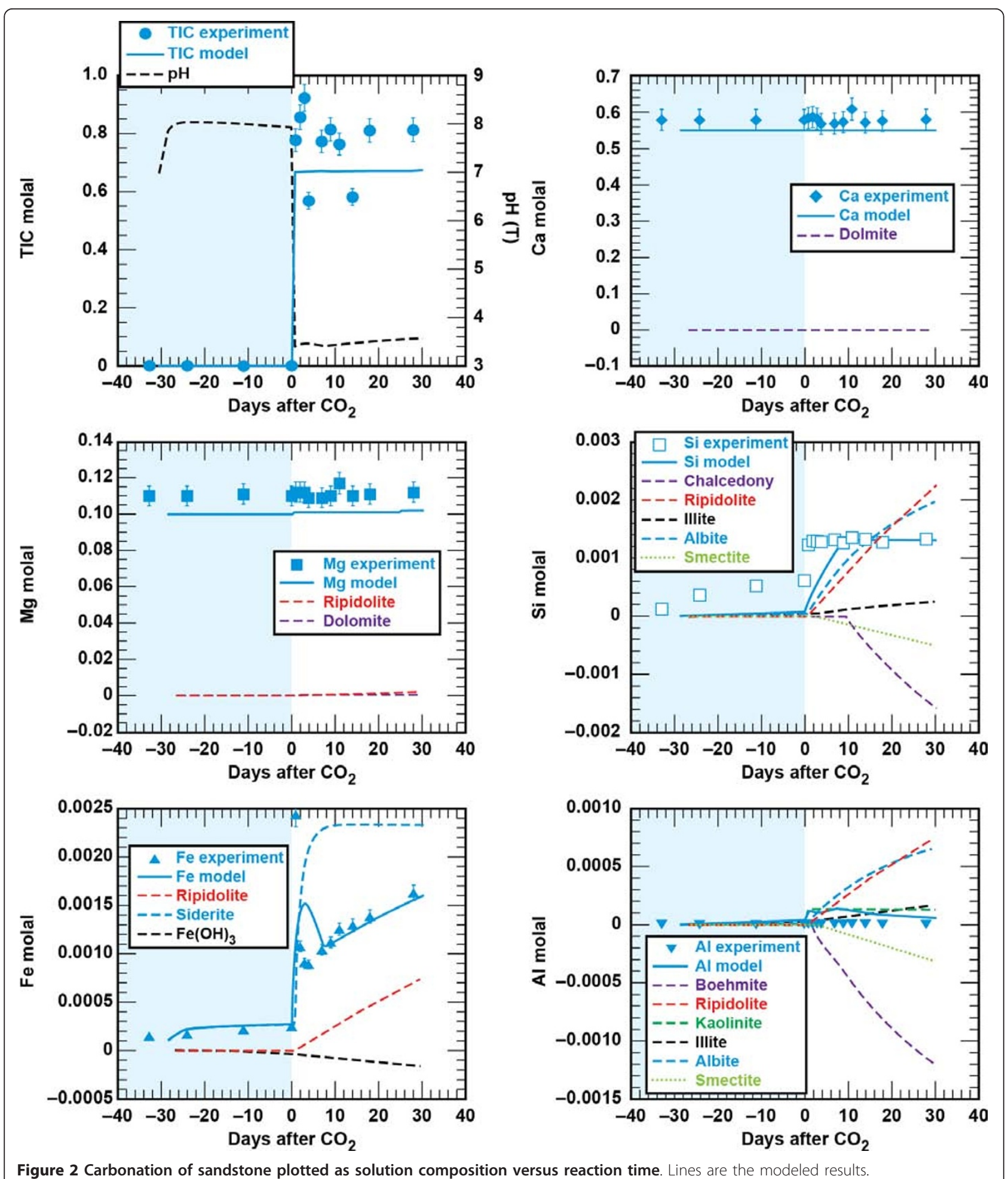

We suspect that dissolution was ultimately limited by diffusion at the cement-solution interface. Less than $40 \%$ of the cement reacted with $\mathrm{CO}_{2}$-rich brine based on the dissolved Mg. We estimate the extent of the cement carbonation reaction from the recovery of $\mathrm{Mg}$ in solution, because the brines are undersaturated with respect to magnesite $\left(\mathrm{MgCO}_{3}\right)$ and there is no indication of $\mathrm{Mg}$ in the carbonate precipitates. Another 

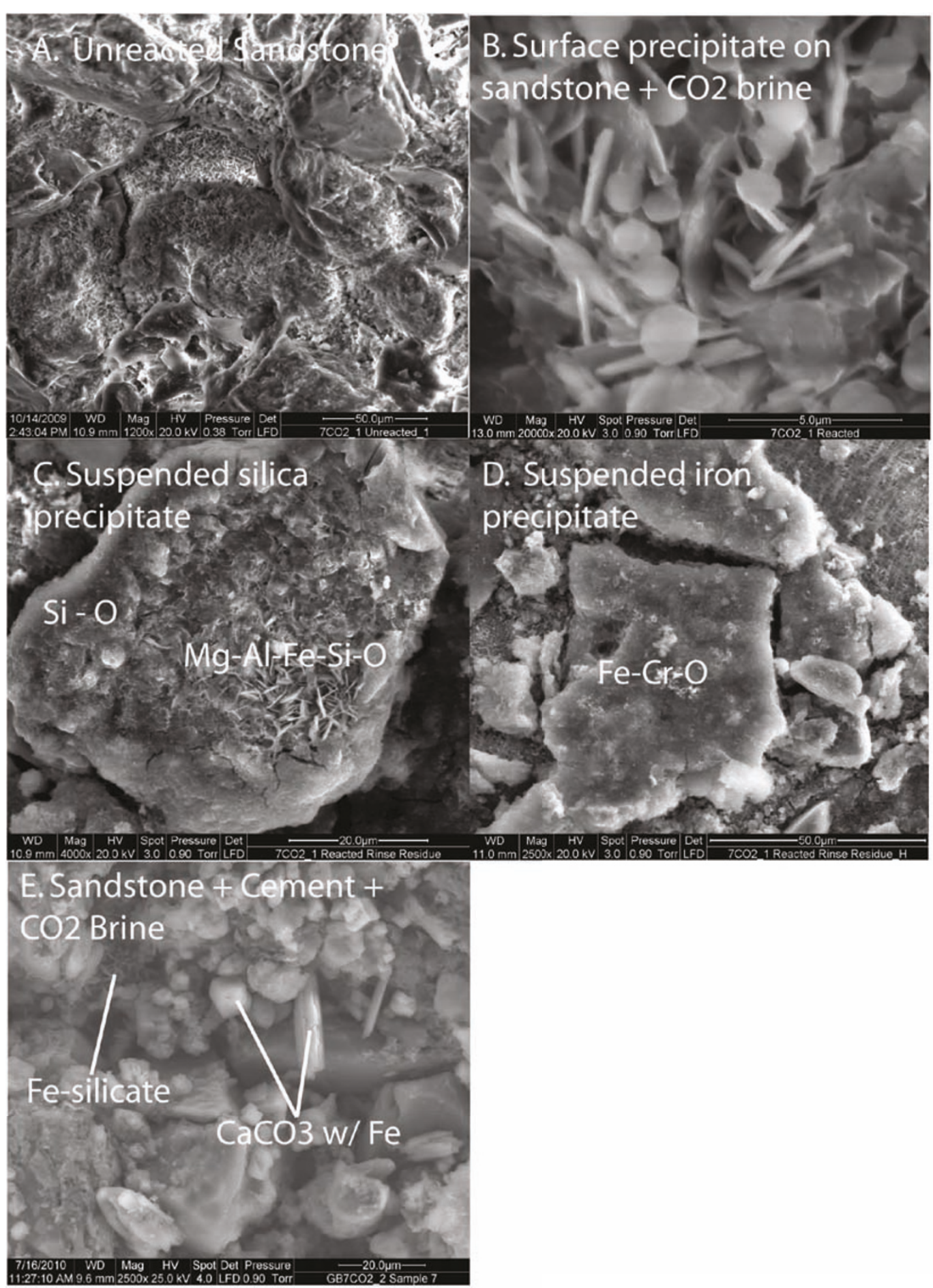

Figure 3 ESEM images of reacted sandstone. (A) Unreacted sandstone consisted of quartz, carbonate cement, and chlorite which lines the pore spaces. Reaction of sandstone with $\mathrm{CO}_{2}$-rich brine produced (B) aluminum hydroxide or aluminosilicate reaction products deposited on the sandstone surface and (C-D) coagulated Si-rich and Fe-rich precipitates in the brine. Reaction of the sandstone with cement and $\mathrm{CO}_{2}$-rich brine produced (E) $\mathrm{Fe}$ - bearing $\mathrm{CaCO}_{3}$ precipitates. 


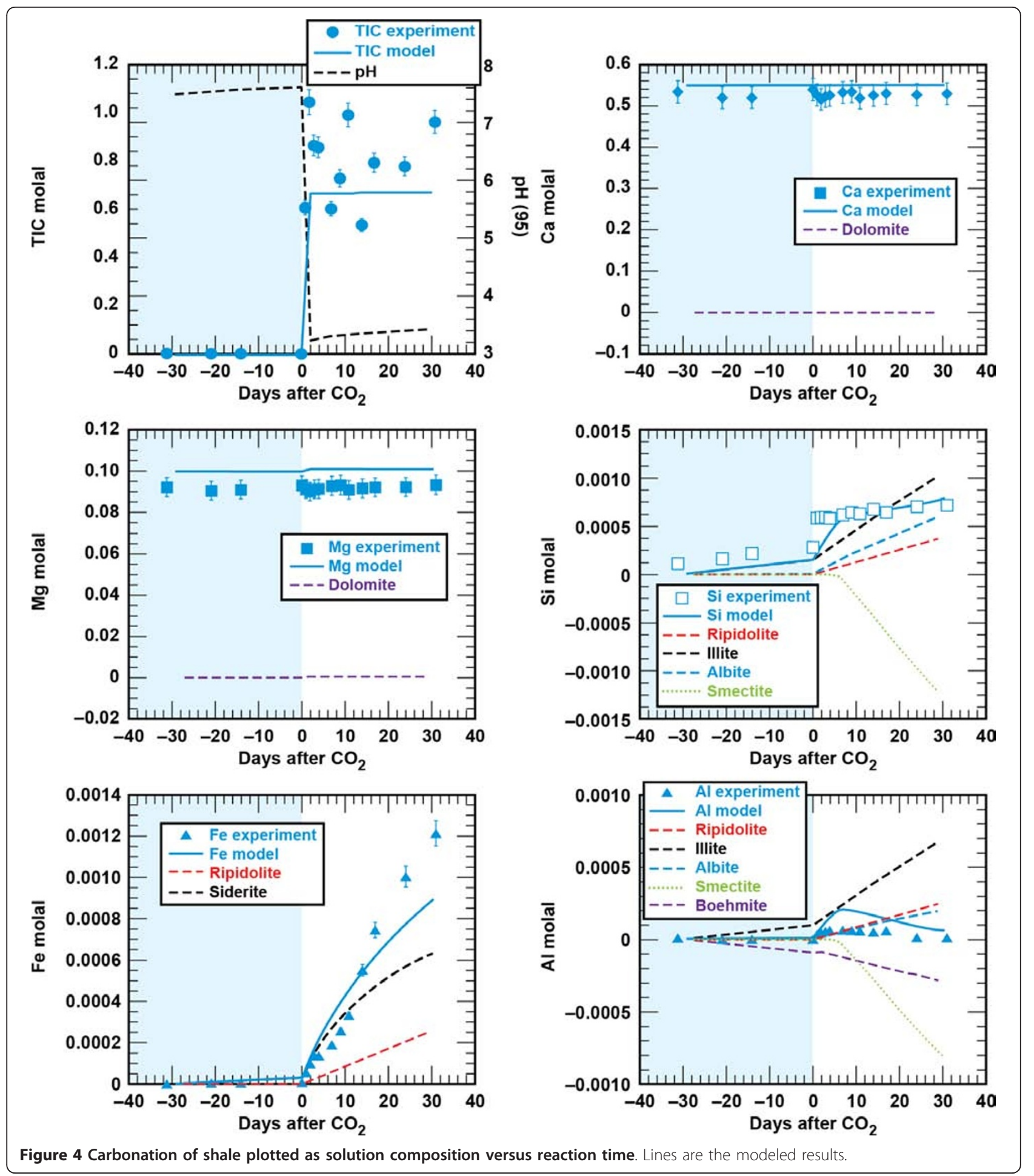

difference between this experiment and the one at lower cement: brine was that the dissolved $\mathrm{Ca}$ increased with time.

Cement - sandstone - brine - $\mathrm{CO}_{2}$

Comparison of the solution chemistry profiles from the cement and cement - sandstone experiments suggest that cement carbonation will drive reaction chemistry in the wellbore environment where the cement contacts sandstone geology (Figures 2 and 8). In the first phase of the experiment, cement hydration produced alkaline solutions with elevated $\mathrm{Ca}$ and depleted $\mathrm{Mg}$. The cement mineral assemblage underwent rapid carbonation when 


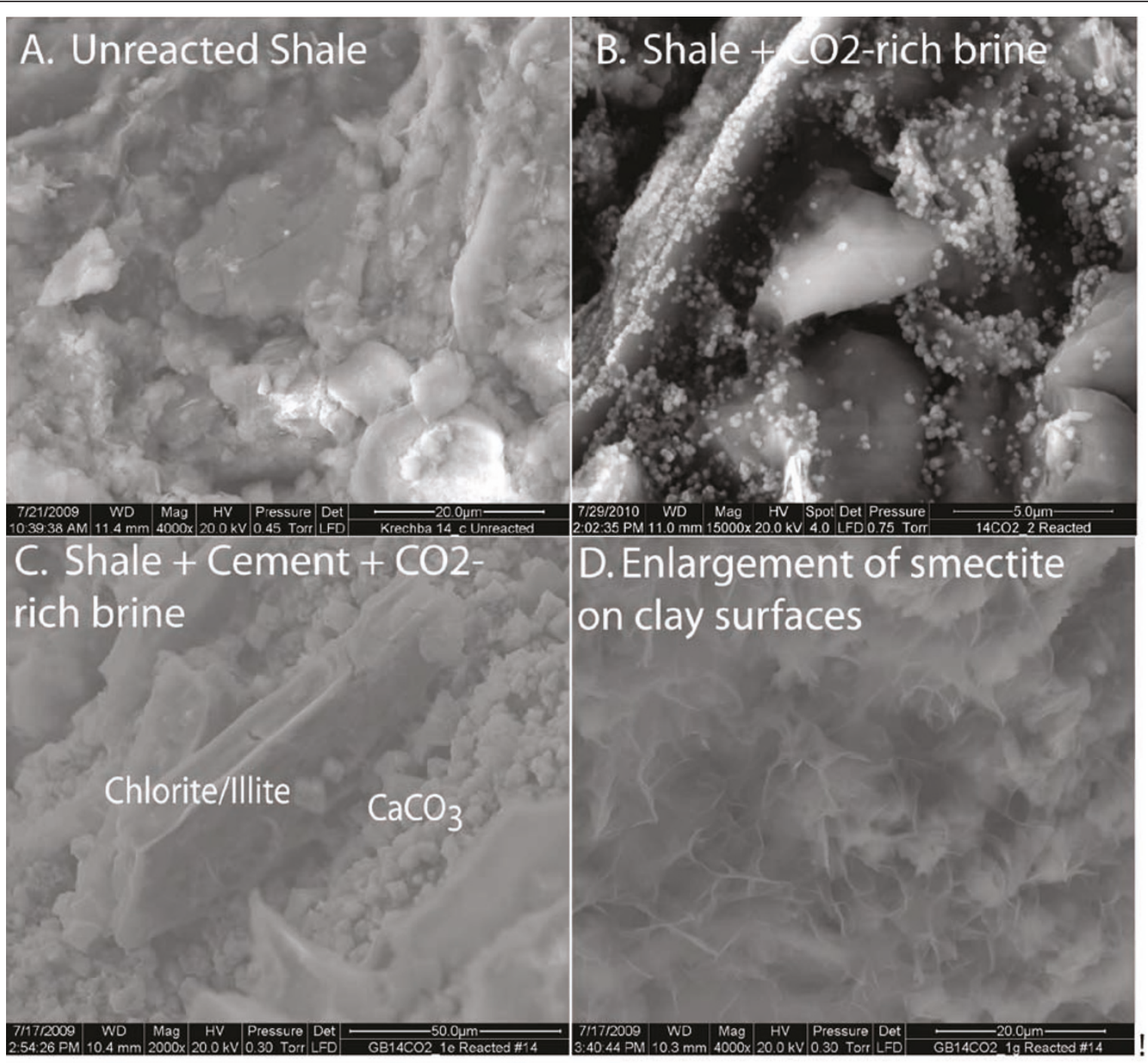

Figure 5 ESEM images of reacted shale. (A) Unreacted shale consisted of fine-grained quartz, illite, and carbonate. When the shale was reacted with $\mathrm{CO}_{2}$-rich brine (B) submicron reaction products deposited on the shale surface and in solution. When the shale reacted with cement and the $\mathrm{CO}_{2}$-rich brine (C-D) there was extensive clay dissolution and precipitation of smectite and calcium carbonate.

supercritical $\mathrm{CO}_{2}$ was injected into the brine. Dissolved $\mathrm{CO}_{2}$ increased by several orders of magnitude to values between 0.6 and 0.8 molal, dissolved Ca decreased, dissolved $\mathrm{Mg}$ increased to the initial brine concentration, dissolved Si also increased to a constant value, and dissolved $\mathrm{Al}$ was quite low.

Despite the dominance for the cement carbonation reactions, there is a chemical signature from the sandstone. Upon injection of the $\mathrm{CO}_{2}$, the dissolved $\mathrm{Fe}$ increased by 3 orders of magnitude to a peak concentration, and then decreased over time to a constant value. This is in sharp contrast to the continued increase in dissolved $\mathrm{Fe}$ when sandstone was reacted with $\mathrm{CO}_{2}$-rich brines in the absence of cement. Qualitative EDX analyses show some Fe in rhombahedral and bladed shaped calcium carbonate alteration products (Figure 3). Fe was also detected in the thin bladed micron-sized silicates that are either residual chlorite or a secondary smectite or iron hydroxide. $\mathrm{Cr}$ is also detected in these micronsized crystals.

\section{Cement - shale - brine - $\mathrm{CO}_{2}$}

Similar to cement - sandstone - $\mathrm{CO}_{2}$ experiment, the cement carbonation chemistry drives the dominant alteration products when shale is reacted with cement and $\mathrm{CO}_{2}$-rich brines (Figure 9). Cement hydration in this experiment was analogous to the other experiments, producing an alkaline solution with elevated $\mathrm{Ca}$ and depleted Mg. Reaction of supercritical $\mathrm{CO}_{2}$, brine, shale and cement yielded $\mathrm{Mg}, \mathrm{Si}$, and Fe profiles that are different from their respective profiles in the cement and 

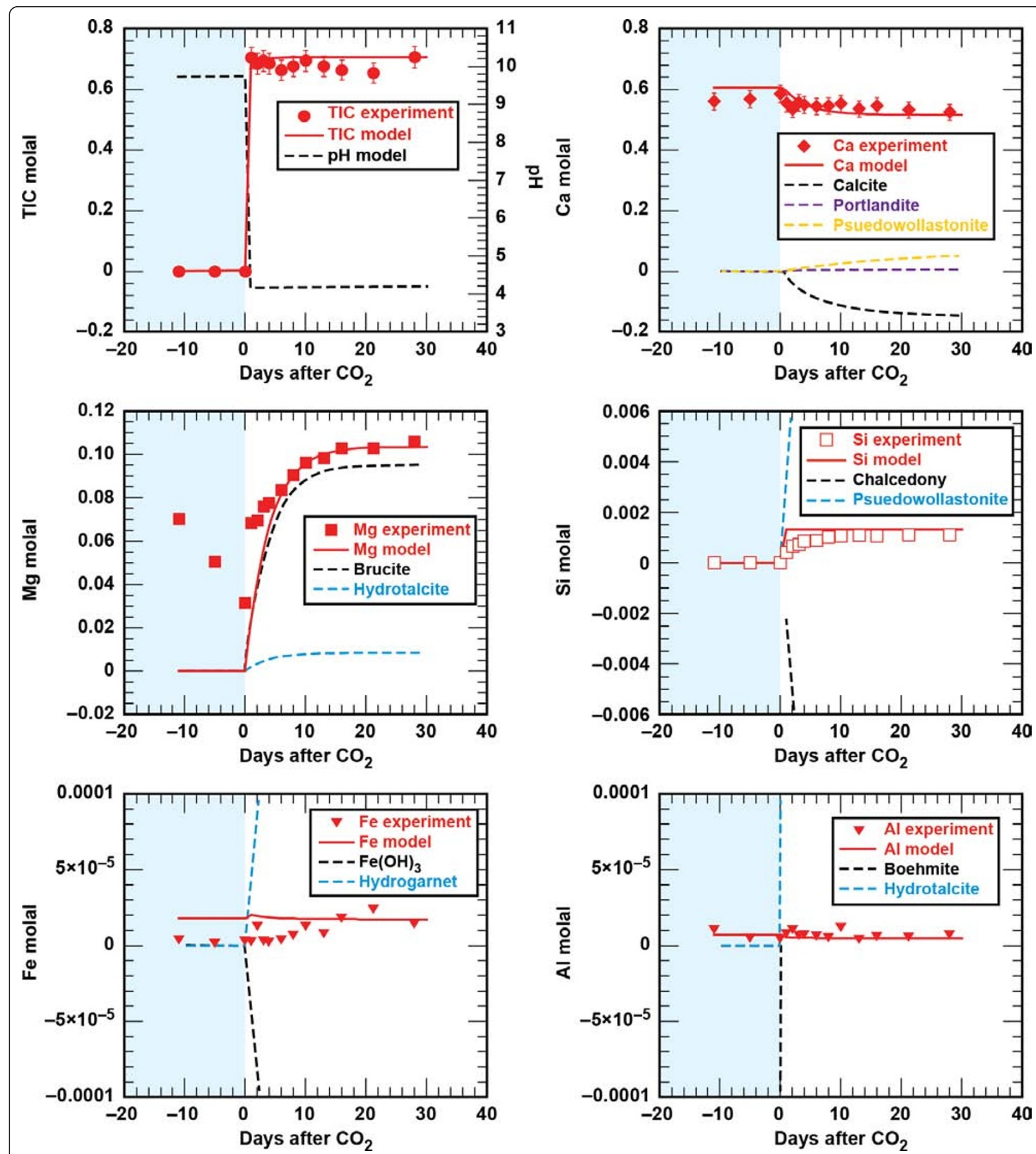

Figure 6 Carbonation of class $\mathrm{G}$ cement as solution composition versus reaction time with a solid(g): $\operatorname{brine}(\mathbf{g}) \approx 1: 68$. Lines are the modeled results.

cement - sandstone experiments. About $80 \%$ of the $\mathrm{Mg}$ removed from the brine during the cement hydration phase of the experiment was recovered in the solution at the experiment end suggesting that $80 \%$ of the bulk cement was carbonated. Dissolved Si increased to a level below that observed for experiments with cement and cement - sandstone. Dissolved Fe approached a value similar to the final concentrations measured in the cement - sandstone experiments, and dissolved $\mathrm{Al}$ was quite low. 


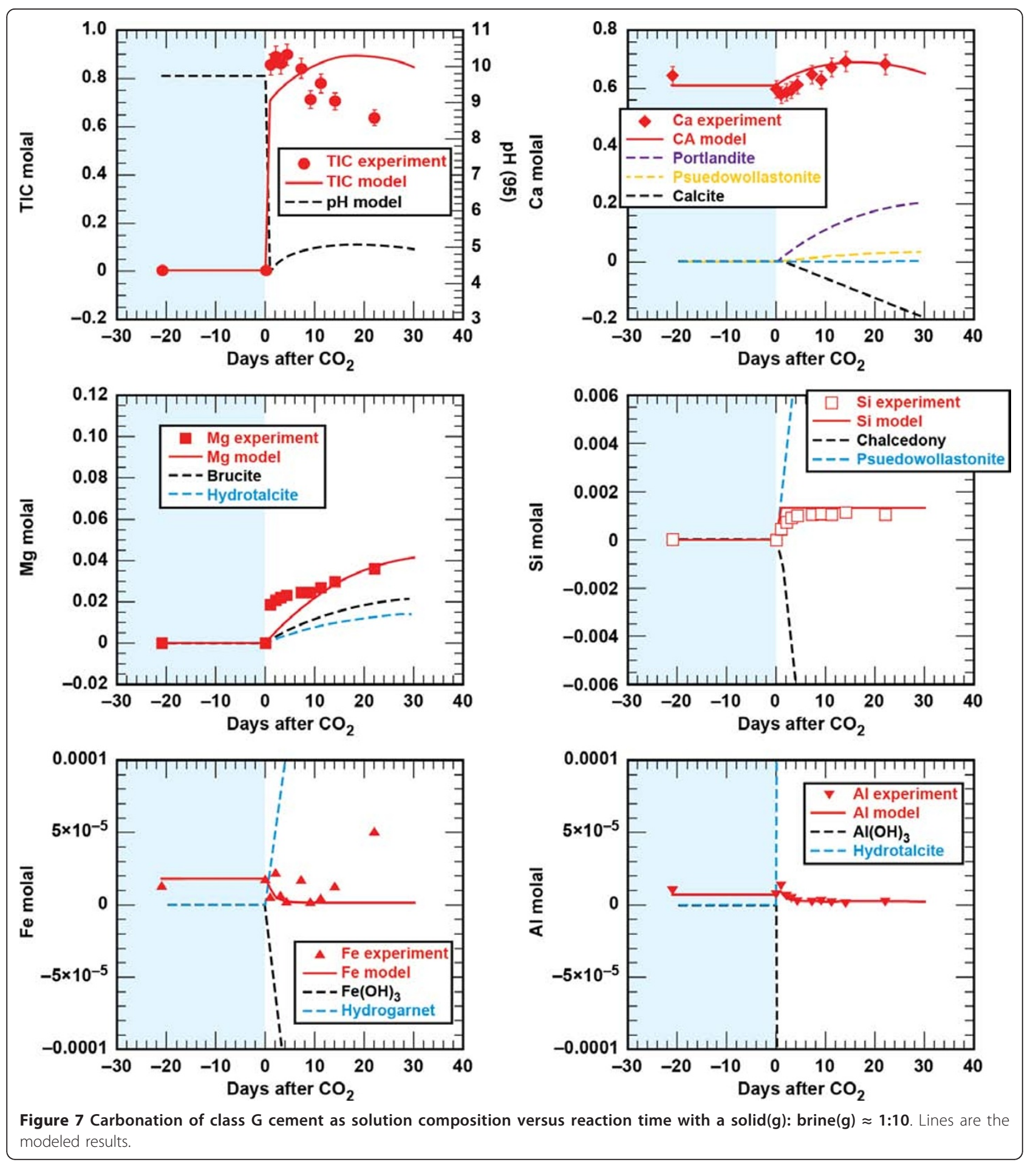

SEM images show that sheet silicates were altered when the shale reacts with the cement and $\mathrm{CO}_{2}$-rich brines (Figure 5). Extensive dissolution groves formed along the edges of the sheet silicates and fibrous precipitates formed on the planar surfaces of the sheet silicates, in addition to calcium carbonate precipitation from cement carbonation.

\section{Geochemical Model}

Geochemical modeling was used to identify a plausible set of reactions consistent from (1) the reported mineralogy from the Krechba reservoir, (2) the changes in brine chemistry observed during each of the experiments, and (3) the alteration products identified at the end of the 


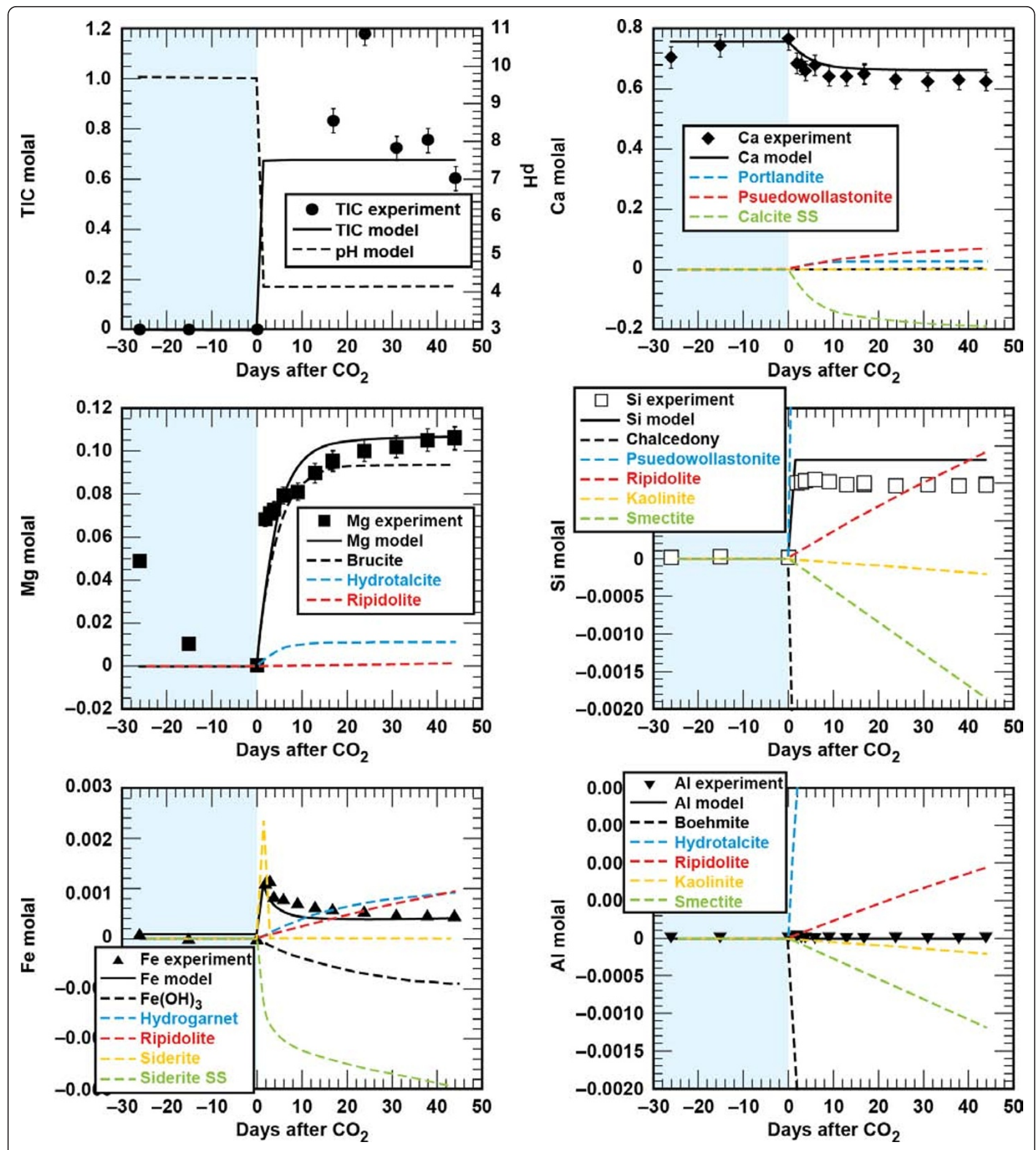

Figure 8 Carbonation of class $\mathrm{G}$ cement and sandstone plotted as solution composition versus reaction time. Lines are the modeled results.

experiments. Our objective in creating the geochemical model was to preserve key attributes, such as mineral composition and dissolution rates, across all experiments to better constrain conceptual models for the assessment of long-term $\mathrm{CO}_{2}$ trapping mechanisms and wellbore and cap rock integrity using reactive-transport simulations. It is important to note that the geochemical model represents one realization that describes six experiments. Details of the modeling approach and related uncertainties can be found in Modeling Uncertainty. 


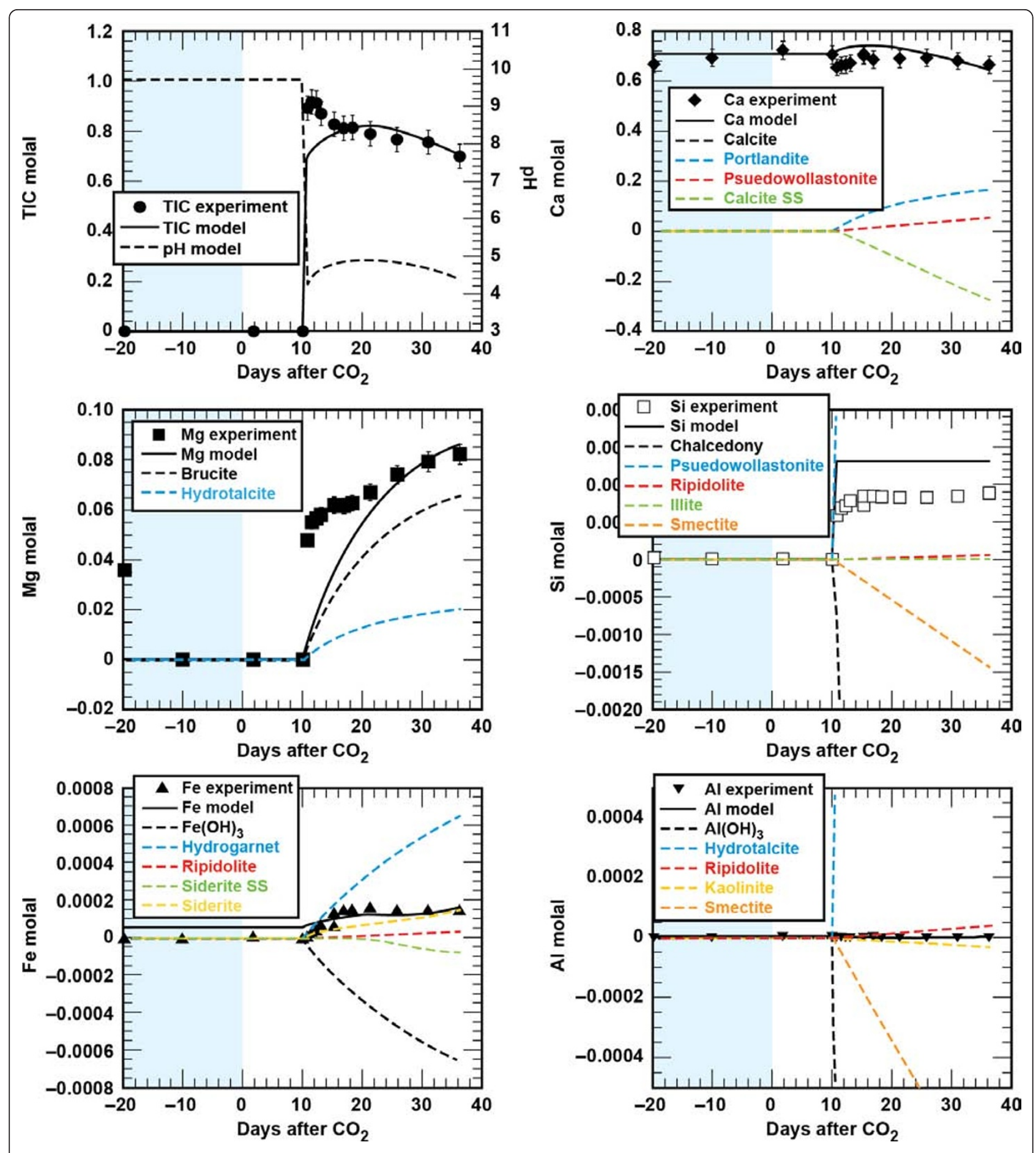

Figure 9 Carbonation of class $\mathrm{G}$ cement and shale plotted as solution composition versus reaction time. Lines are the modeled results.

\section{Sandstone Reservoir and Shale Cap Rock Geochemical} Model

The geochemical model for the reaction of sandstone and shale with $\mathrm{CO}_{2}$ and brine is a simple one, in which chlorite, illite, albite, quartz and carbonate minerals partially dissolve and boehmite, smectite, $\mathrm{Fe}(\mathrm{OH})_{3}$ and amorphous silica precipitate (Table 5). The same geochemical model is used to describe both the storage reservoir and the cap rock, because the mineralogy is the same for both rock types, although the relative proportion of the minerals differs.

Comparison of the measured and simulated data shows that this simple model adequately describes the 
experiments (Figures 2 and 4). In both experiments dolomite dissolution predicts dissolved $\mathrm{Ca}$ and $\mathrm{Mg}$ to within $5 \%$ of the experimental values. Upon injection of $\mathrm{CO}_{2}$ into the sandstone experiment dissolved $\mathrm{Si}$ from albite, chlorite, and lesser amounts of illite dissolution is offset by silica precipitation once chalcedony saturation is exceeded and some smectite precipitation. In the sandstone experiment small amounts of illite limit the amount of smectite precipitation, which is tied to the illite surface area. However, in the shale experiment, where there is significantly more illite (44\%) than in the sandstone experiment (1.5\%), smectite precipitation effectively limits the dissolved $\mathrm{Si}$ to concentrations below chalcedony saturation. Pre- $\mathrm{CO}_{2}$ and the abrupt changes in dissolved $\mathrm{Si}$, possibly from the dissolution of fines that occurred when $\mathrm{CO}_{2}$ was first injected into the sandstone experiment, are not captured in the model fits. Both siderite and chlorite dissolution contribute to the dissolved Fe concentrations in both experiments. The sharp decrease in dissolved $\mathrm{Fe}$ in the sandstone experiment can be modeled as $\mathrm{Fe}(\mathrm{OH})_{3}$ precipitation and the depletion of dissolved oxygen present in the stock solutions that were prepared at atmospheric conditions. Any dissolved oxygen appears to have been quickly consumed in the shale experiment as no concentration peaks were observed. The low dissolved aluminum concentrations are a product of secondary precipitation of boehmite, kaolinite, and smectite.

\section{Wellbore Geochemical Model}

We derive the wellbore geochemical model by combining the lithologic model with cement hydration and carbonation models described below. Carbonation of the hydrated cement assemblage was modeled with a set of carbonate minerals, amorphous $\mathrm{SiO}_{2}$ (as chalcedony), $\mathrm{Fe}(\mathrm{OH})_{3}$, and boehmite or amorphous $\mathrm{Al}(\mathrm{OH})_{3}$ (dependent on the cement: brine; Table 5, Figures 6 and 7). Comparison of the measured and simulated data shows that this simple model adequately describes the data and captures the effects of reacting varying amounts of cement with the $\mathrm{CO}_{2}$-rich brine. At low solid to brine ratios $(1: 68 \mathrm{~g} / \mathrm{g})$, calcite precipitation results in a decrease in dissolved $\mathrm{Ca}$, brucite and hydrotalcite dissolution result in the recovery of dissolved $\mathrm{Mg}$ to initial values, and $\mathrm{SiO}_{2}, \mathrm{Fe}(\mathrm{OH})_{3}$ and boehmite precipitation limit the amount of dissolved $\mathrm{Si}$, $\mathrm{Fe}$, and $\mathrm{Al}$ as $\mathrm{CSH}$, Fe-hydrogarnet and hydrotalcite dissolved during the carbonation process. At higher solid to brine ratios $(1: 10 \mathrm{~g} / \mathrm{g})$, where roughly $60 \%$ more cement reacted with brine (based on percent recovery of dissolved $\mathrm{Mg}$ and the initial amount of cement), the model captures the increase in dissolved $\mathrm{Ca}$ with cement carbonation and higher dissolved $\mathrm{Al}$ concentrations when amorphous $\mathrm{Al}$ $(\mathrm{OH})_{3}$ is used to control $\mathrm{Al}$ solubility. Recall, that rates used here are conditional to the experiments and scale with dissolved $\mathrm{Mg}$ recovery.

The combination of the lithology - brine $-\mathrm{CO}_{2}$ and cement carbonation models reproduces brine chemistry evolution observed during the carbonation phases of the composite experiments (Figures 8 and 9). As might be expected, cement carbonation dominates the geochemical reactions in the wellbore environment, largely because cement reactivity masks contributions from the much less reactive sandstone and shale minerals. Dissolved $\mathrm{Ca}$ can be accounted for by the carbonation of portlandite and CSH. Dissolved Mg can be accounted for by dissolution of brucite and hydrotalcite (where the extent of cement carbonation is fit to the proportion of Mg recovered). Although chalcedony precipitation accounts the bulk of Si during carbonation, the higher inputs of $\mathrm{Si}$ and $\mathrm{Ca}$ result in smectite precipitation in both the cement - sandstone and cement - shale experiments. This model result agrees with the appreciable amount of smectite observed in the cement - shale experiment. One added parameter specific to the lithology - cement - brine - $\mathrm{CO}_{2}$ experiments was the introduction of a ferroan calcite solid solution, which limited the dissolved Fe from chlorite dissolution in the sandstone and shale experiments.

\section{Conclusions}

Our research shows that relatively simple geochemical models can describe the dominant reactions that will occur when $\mathrm{CO}_{2}$ is stored in deep saline aquifers sealed with overlying shale cap rocks, and when $\mathrm{CO}_{2}$ reacts at the interface between cement and reservoir and shale cap rock. Although the experiments and modeling reported here are specific to the $\mathrm{CO}_{2}$ storage at the Krechba site, the model may be applicable to other storage sites with similar geology. Development of these relatively simple geochemical models is needed to assess long-term $\mathrm{CO}_{2}$ trapping mechanisms, cap rock and wellbore integrity in more computationally intensive reactive-transport simulations that couple chemistry, flow, and possibly geomechanics. As is expected, $\mathrm{Al} / \mathrm{Fe}$ silicate dissolution drives the geochemical alterations within the reservoir and cap rock pore space. Addition of $\mathrm{CO}_{2}$ lowers the $\mathrm{pH}$ and promotes silicate dissolution and amorphous silica, smectite and boehmite precipitation. The dissolved Fe may be a source of long-term mineral trapping of $\mathrm{CO}_{2}$ and the precipitation of secondary Fe-carbonates, clays and hydroxides could alter reservoir and seal permeability by clogging pores and fracture networks. In agreement with other studies we find that alkaline cements are highly reactive in the presence of $\mathrm{CO}_{2}$-rich brines and are quickly transformed to carbonate minerals and amorphous silica. These reactions can be easily modeled as 
the transformation of portlandite, and $\mathrm{Ca}$ - and $\mathrm{Mg}$ silicates to aragonite or calcite and amorphous silica. Finally, we find that dissolved Mg common in deep saline brines will react with the wellbore cement to form poorly-crystalline solids. Additional research is required to assess mineral structure of the Mg-rich cement phase, as it could not be identified in this study and to assess what the impact of the $\mathrm{Mg}$ - induced alteration may have on wellbore integrity.

\section{Acknowledgements}

This document was prepared as an account of work sponsored by an agency of the United States government. Neither the United States government nor Lawrence Livermore National Security, LLC, nor any of their employees makes any warranty, expressed or implied, or assumes any legal liability or responsibility for the accuracy, completeness, or usefulness of any information, apparatus, product, or process disclosed, or represents that its use would not infringe privately owned rights. Reference herein to any specific commercial product, process, or service by trade name, trademark, manufacturer, or otherwise does not necessarily constitute or imply its endorsement, recommendation, or favoring by the United States government or Lawrence Livermore National Security, LLC. The views and opinions of authors expressed herein do not necessarily state or reflect those of the United States government or Lawrence Livermore National Security, LLC, and shall not be used for advertising or product endorsement purposes.

This work performed under the auspices of the U.S. Department of Energy by Lawrence Livermore National Laboratory under Contract DE-AC5207NA27344.

We thank three anonymous reviewers for their comments which significantly improved the manuscript. We acknowledge funding from and data provided by the Joint Industry Project (a consortium of BP, Statoil and Sonatrach) and the U.S. Department of Energy to investigate the importance of geochemical alteration at the In Salah $\mathrm{CO}_{2}$ storage project. We also thank Bill Ralph for his contributions to experiments early in the project and Mike Singleton and Pihong Zhao for chemical analyses, and Phil Ringrose for interest in geochemistry.

\section{Authors' contributions}

SAC is the primary author. She designed and directed the experiments, WWM modeled the experiments, and SCT conducted the experiments. All authors have read and approved the final manuscript.

\section{Competing interests}

The authors declare that they have no competing interests.

Received: 1 March 2011 Accepted: 11 November 2011 Published: 11 November 2011

\section{References}

1. In Salah Gas Stockage de $\mathrm{CO}_{2}$. [http://www.insalahco2.com].

2. Oldenburg CM, Jordan PD, Nicot J-P, Mazzoldi A, Gupta AK, Bryant SL: Leakage risk assessment of the In Salah $\mathrm{CO}_{2}$ storage project: Applying the certification framework in a dynamic context. Energy Procedia 2011, 4:4154-4161.

3. Dodds K, Watson M, Wright I: Evaluation of risk assessment methodologies using the In Salah $\mathrm{CO}_{2}$ stroage project as a case history. Energy Procedia 2011, 4:4161-4169.

4. Iding $M$, Ringrose $P$ : Evaluating the impact of fractures on the performance of the In Salah $\mathrm{CO}_{2}$ storage site. I J Greenhouse Gas Control 2010, 4:242-248.

5. Rutqvist J, Vasco DW, Myer L: Coupled reservoir-geomechanical analysis of $\mathrm{CO}_{2}$ injection and ground deformations at In Salah, Algeria. / J Greenhouse Gas Control 2010, 4:225-230.

6. Michael K, Globab A, Shulakova V, Ennis-King J, Allinson G, Sharma S, Aiken T: Geological storage of $\mathrm{CO}_{2}$ in saline aquifers - $\mathrm{A}$ review of the experience from existing storage operations. I J Greenhouse Gas Control 2010, 4:659-667.

7. Vasco DW, Ferretti A, Novali F: Reservoir monitoring and characterization using satellite geodetic data: interferometric synthetic aperture radar observations from the Krechba field Algeria. Geophysics 2008, 73: WA113-WA122.

8. Vasco DW, Ferretti A, Novali F, Bissel F, Ringrose P, Mathieson A, Wright I: Satellite-based measurements of surface deformation reveal fluid flow associated with the geological storage of carbon dioxide. Geophysical Research Letters 2010, 37:L03303.

9. Morse JP, Hao Y, Foxall W, McNab W: A study of injection-induced mechanical deformation at the In Salah $\mathrm{CO}_{2}$ storage project. / J Greenhouse Gas Control 2011, 5:270-280.

10. Mathieson A, Wright IW, Roberts D, Ringrose P: Satellite imaging to monitor $\mathrm{CO}_{2}$ movement at Krechba, Algeria. Energy Procedia 2009, 1:2201-2209.

11. Onuma T, Ohkaws S: Detection of surface deformation related with $\mathrm{CO}_{2}$ injection by DInSAR at In Salah, Algeria. Energy Procedia 2009, $1: 2177-2184$

12. Kutchko BG, Strazisar BR, Dzombak DA, Lowry GV, Thaulow N: Degradation of well cement by $\mathrm{CO}_{2}$ under geologic sequestration conditions. Environmental Science and Technology 2007, 41:4787-4792.

13. Barlet-Gouedard V, Rimmele G, Porcherie O, Quisel N, Desroches J: A solution against well cement degradation under $\mathrm{CO}_{2}$ geological storage environment. / J Greenhouse Gas Control 2009, 3:206-216.

14. Carey JW, Wigand M, Chipera SJ, WoldeGabriel G, Pawar R, Lichtner PC, Wehner SC, Raines MA, Guthrie GD: Analysis and performance of oil well cement with 30 years of $\mathrm{CO}_{2}$ exposure from the SACROC Unit, West Texas, USA. I J Greenhouse Gas Control 2007, 1:75-85.

15. Crow W, Williams B, Carey JW, Celia M, Gasda S: Wellbore integrity of a natural $\mathrm{CO}_{2}$ producer. Energy Procedia 2009, 1:3561-3569.

16. Duguid A: An estimate of the time to degrade the cement sheath in a well exposed to carbonated brine. Energy Procedia 2009, 1:3181-3188.

17. Wigand M, Kazuba JP, Carey JW, Hollis WK: Geochemical effects of $\mathrm{CO}_{2}$ sequestration on fractured wellbore cement at the cement cap rock interface. Chemical Geology 2009, 265:122-133.

18. Huet BM, Prevost $\mathrm{JH}$, Scherer GW: Quantitative reactive transport modeling of Portland cement in $\mathrm{CO}_{2}$-saturated water. I J Greenhouse Gas Control 2010, 4:561-574.

19. Emberley S, Hutcheon I, Shevalier M, Durocher K, Mayer B, Gunter WD, Perkins $\mathrm{EH}$ : Monitoring of fluid-rock interaction and $\mathrm{CO}_{2}$ storage through produced fluid sampling at the Weyburn $\mathrm{CO}_{2}$-injection enhanced oil recovery site, Saskatchewan, Canada. App/ Geochem 2005, 20:1131-1157.

20. Kaszuba JP, Janecky DR, Snow MG: Carbon dioxide reaction processes in a model brine aquifer at $200^{\circ} \mathrm{C}$ and 200 bars: implications for geologic sequestration of carbon. App/ Geochem 2003, 18:1065-1080.

21. Janecky DR, Snow MG: Experimental evaluation of mixed fluid reactions between supercritical carbon dioxide and $\mathrm{NaCl}$ brine: relevance to the integrity of a geologic carbon repository. Chemical Geology 2005, 217:277-293.

22. Palandri JL, Rosenbauer RJ, Kharaka YK: Ferric iron in sediments as a novel $\mathrm{CO}_{2}$ mineral trap: $\mathrm{CO}_{2}-\mathrm{SO}_{2}$ reaction with hematite. Appl Geochem 2005, 20:2038-2048.

23. Kharaka YK, Hovorka SD, Gunter WD, Knauss KG, Freifeld BM: Gas-waterrock interactions in Frio Formation following $\mathrm{CO}_{2}$ injection: Implications for the storage of greenhouse gases in sedimentary basin. Geology 2006, 34:577-580.

24. LU P, Fu Q, Seyfried WE Jr, Hereford A, Zhu C: Navajo Sandstone-brine- $\mathrm{CO}_{2}$ interaction: implications for geologic carbon sequestration. Environ Earth Sci 2011, 62:101-118.

25. $\mathrm{Xu} T$, Apps JA, Pruess $\mathrm{K}$ : Reactive geochemical transport simulation to study mineral trapping for $\mathrm{CO}_{2}$ disposal in deep arenaceous formations. J Geophysical Research-Solid Earth 2003, 108:2071.

26. Xu T, Kharaka YK, Daughty C, Freifeld BM, Daley TM: Reactive transport modeling to study changes in water chemistry induced by $\mathrm{CO}_{2}$ injection at the Frio-I Brine Pilot. Chemical Geology 2010, 271:153-164.

27. Johnson JW, Nitao JJ, Knauss KG: Reactive transport modeling of $\mathrm{CO}_{2}$ storage in saline aquifers to elucidate fundamental processes, trapping mechanisms and sequestration partitioning. In Geological Storage of Carbon Dioxide. Volume 233. Edited by: Baines SJ, Worden RH. Geological Society, London, Special Publications; 2004:107-128. 
28. White SP, Allis RG, Moore J, Chidsey T, Morgan C, Gwynn W, Adams M: Simulation of reactive transport of injected $\mathrm{CO}_{2}$ on the Colorado Plateau, Utah, USA. Chemical Geology 2005, 217:387-405.

29. Zerai $\mathrm{B}$, Saylor $\mathrm{BZ}$, Matisoff $\mathrm{G}$ : Computer simulation of $\mathrm{CO}_{2}$ trapped through mineral precipitation in the Rose Run Sandstone, Ohio. Appl Geochem 2006, 21:223-240.

30. Lui F, Lu P, Zhu C, Xiao Y: Coupled reactive flow and transport modeling of $\mathrm{CO}_{2}$ sequestration in the Mt. Simon sandstone formation, Midwest $\mathrm{U}$. S.A. Intern J Greenhouse Gas Control 5:294-307.

31. Gherardi $F, X u T$, Pruess P: Numerical modeling of self-limiting and selfenhancing cap rock alteration induced by $\mathrm{CO}_{2}$ storage in a depleted gas reservoir. Chemcial Geology 2007, 244:103-129.

32. Guas I, Azaroual $M$, Czernichowski-Lauriol I: Reactive transport modeling of the impact of $\mathrm{CO}_{2}$ injection on the clayey rock at Sleipner (North Sea). Chemical Geology 2005, 217:319-337.

33. Armitage PJ, Worden RH, Faulkner DR, Aplin AC, Butcher AR, lliffe J: Diagenetic and sedimentary controls on porosity in Lower Carboniferous fine-grained lithologies, Krechba field, Algeria: A petrological study of a cap rock to a carbon capture site. Marine and Petroleum Geology 2010, 27:1395-1410.

34. Parkhurst DL, Appelo CAJ: User's Guide to PHREEQC (Version 2) - A Computer Program for Speciation, Batch-reaction, One-dimensional Transport, and Inverse Geochemical Calculations. U.S. Geological Survey Water-Resources Investigations Report 99-4259 1999, 312

35. Johnson JW, Oelkers EH, Helgeson HC: SUPCRT92: A software package for calculating the standard molal thermodynamic properties of minerals, gases, aqueous species, and reactions from 1 to 5000 bar and 0 to $1000^{\circ} \mathrm{C}$. Computers and Geoscience 1992, 18:899-947.

36. CEMDATA Thermodynamic data for hydrated solids in Portland cement system $\left(\mathrm{CaO}-\mathrm{Al}_{2} \mathrm{O}_{3}-\mathrm{SiO}_{2}-\mathrm{CaSO}_{4}-\mathrm{CaCO}_{3}-\mathrm{Fe}_{2} \mathrm{O}_{3}-\mathrm{MgO}-\mathrm{H}_{2} \mathrm{O}\right)$. [http://www. empa.ch/cemdata].

37. Matschei T, Lothenbach B, Glasser FP: The AFM phase in Portland cement. Cement and Concrete Research 2007, 37:118-130.

38. Lothenbach B, Matschei T, Möschner G, Glasser FP: Thermodynamic modeling of the effect of temperature on the hydration and porosity of Portland cement. Cement and Concrete Research 2008, 38:1-81.

39. Duan $\mathrm{ZH}$, Sun $\mathrm{R}$ : An improved model calculating $\mathrm{CO}_{2}$ solubility in pure water and aqueous $\mathrm{NaCl}$ solutions from 273 to $533 \mathrm{~K}$ and from 0 to 2000 bar. Chemical Geology 2003, 193:257-271.

40. Palanrdi JL, Kahraka YK: A complication of rate parameters of watermineral interactions kinetics for application to geochemical modeling. USGS Open File Report 2004-1068.

41. Houston J, Maxwell RS, Carroll S: Transformation of meta-stable calcium silicate hydrates to tobermorite: reaction kinetics and molecular structure from XRD and NMR spectroscopy. Geochemical Transactions 2009, 10:1.

doi:10.1186/1467-4866-12-9

Cite this article as: Carroll et al:: Experimental Study of Cement Sandstone/Shale - Brine - $\mathrm{CO}_{2}$ Interactions. Geochemical Transactions 2011 12:9.

\section{Submit your next manuscript to BioMed Central and take full advantage of:}

- Convenient online submission

- Thorough peer review

- No space constraints or color figure charges

- Immediate publication on acceptance

- Inclusion in PubMed, CAS, Scopus and Google Scholar

- Research which is freely available for redistribution 